\title{
A comparative ideotype, yield component and cultivation value analysis for spring wheat adaptation in Finland
}

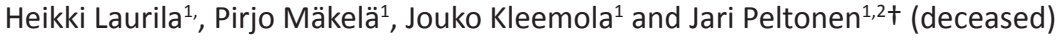 \\ ${ }^{1}$ Department of Agricultural Sciences, University of Helsinki, P.O. Box 27, \\ FI-00014 University of Helsinki, Finland \\ ${ }^{2}$ GrowProfit, http://www.growprofit.fi, Finland \\ e-mail: heikki.laurila@logica.com
}

\begin{abstract}
In this study Mixed structural covariance, Path and Cultivation Value analyses and the CERES-Wheat crop model were used to evaluate vegetation and yield component variation affecting yield potential between different highlatitude $\left(>60^{\circ} \mathrm{N}\right.$ lat.) and mid-European $\left(<60^{\circ} \mathrm{N}\right.$ lat.) spring wheat (Triticum aestivum L.) genotypes currently cultivated in southern Finland. Path modeling results from this study suggest that especially grains/ear, harvest in$\operatorname{dex}(\mathrm{HI})$ and maximum 1000 kernel weight were significant factors defining the highest yield potential. Mixed and Cultivation value modeling results suggest that when compared with genotypes introduced for cultivation before 1990s, modern spring wheat genotypes have a significantly higher yielding capacity, current high yielding midEuropean genotypes even exceeding the $5 \mathrm{t} \mathrm{ha}^{-1}$ non-potential baseline yield level $\left(\mathrm{y}_{\mathrm{b}}\right)$. Because of a forthcoming climate change, the new high yielding wheat genotypes have to adapt for elevated temperatures and atmospheric $\mathrm{CO}_{2}$ growing conditions in northern latitudes. The optimized ideotype profiles derived from the generic high-latitude and mid-European genotypes are presented in the results. High-latitude and mid-European ideotype profiles with factors estimating the effects of concurrent elevated $\mathrm{CO}_{2}$ and temperature levels with photoperiodical daylength effects can be utilized when designing future high yielding ideotypes adapted to future growing conditions. The CERES-Wheat ideotype modeling results imply, that with new high yielding mid-European ideotypes, the non-potential baseline yield $\left(\mathrm{y}_{\mathrm{b}}\right)$ would be on average $5150 \mathrm{~kg} \mathrm{ha}^{-1}$ level (+108\%) vs. new high-latitude ideotypes ( $\left.\mathrm{y}_{\mathrm{b}} 4770 \mathrm{~kg} \mathrm{ha}^{-1}, 100 \%\right)$ grown under the elevated $\mathrm{CO}_{2(700 \mathrm{ppm})} \times$ temperature ${ }_{\left(+3^{\circ} \mathrm{C}\right)}$ growing conditions projected by the year 2100 climate change scenario in southern Finland.
\end{abstract}

Key words: ideotype profile, generic genotype, yield component, spring wheat, grain yield, climate change, cultivation value, adaptation strategy, CERES-Wheat model, Finland

\section{Introduction}

Donald (1968) defined the concept of a spring wheat ideotype as the optimal wheat genotype with a maximum potential for grain yield production under optimal growing conditions. A crop ideotype in cereal breeding can be described as a plant model system, which is expected to yield greater quantity or quality of grain, oil or other useful product when developed as a cultivar.

In agronomic studies the Donald's original ideotype concept has been reviewed by Sedgley (1991) and by Reynolds et al. (1994) for yield potential estimations in modern wheat cultivars. According to Sedgley (1991) Donald's ideotype concept explains both the optimal resource allocation and translocation of assimilates maximizing crop yield and the relationships between yield, harvest index $(\mathrm{HI})$ and morphological characters in monoculture and variety mixture growing environments. Later on Donald and Hamblin (1983) expanded the Donald's ideotype concept with additional climatic, edaphic, disease, pest and stress ideotype concepts. Sedgley (1991) evaluated the two antagonist components in Donald's ideotype, the optimal communal ideotype for cereals maximizing yield potential with uniculm growth habit without side tillers, short stem and narrow erect leaves and the adversary competitive ideotype with freely tillering and tall stature with large leaves.

The Donald's ideotype concept have been widely studied and reviewed for a variety of crops and traits, e.g. in plant canopy and leaf architecture modeling (Carvalho et al. 1978), in ideotype-based breeding strategies for wheat with genotypexenvironment (G×E) covariances (Sedgley 1991, de la Vega et al. 2002), in crop modeling studies (Boote et al. 2001) and in phenotypic plasticity studies for wheat yields (Sadras et al. 2009). According to 
Sadras et al. (2009) high yield and low plasticity for yield were coupled with early anthesis, long anthesis duration and low plasticity of post-anthesis development with wheat genotypes grown in Mexico. In Finland Peltonen et al. (1993) applied the Cultivation value model (Weizensorten und Backqualität 1990) to estimate the cultivation scoring and ranking values with adaptation plasticity, cultivation certainty and baking quality components for current high yielding wheat genotypes. In this study the Cultivation value model was evaluated for high-latitude (HiL) and mid-European (MidE) ideotype profiles (ItPrf).

The benefits of applying both statistical and dynamic, mechanistic crop models for Donald's ideotype evaluation have been reviewed by Boote et al. (2001) and de la Vega et al. (2002). Crop models used in plant breeding should be both dynamic varying over edaphic and weather conditions and mechanistic simulating physiological processes like phenological development, source-sink relationships and translocation of assimilates. According to Boote et al. (2001) crop models simulate genetic improvement and variability within a species by evaluating intracultivar variation and how crop models can be used to hypothesize ideotypes for specific growing environments. In this study the CERES-Wheat/DSSAT dynamic crop model (Ritchie \& Otter 1985, Jones et al. 2003) was used to define genetic coefficients for MidE (Laurila 1995) and HiL (Laurila 2001) ideotype profiles. The genetic coefficients in the CERES-Wheat model control both wheat phenological development and grain yield components.

Statistical structural and clustering analysis and modeling have been extensively applied in biometrics and biometrical analysis to detect interacting and indirect covariances, trends and underlying variables in the experimental data. The techniques commonly used are Mixed Structural Covariance Analysis (Littel et al. 1996), Path coefficient analysis (Wright 1923) and Principal Component Analysis (PCA, de la Vega et al. 2002, Reynolds et al. 2007).

In Finland Öfversten and Nikander (1996) applied the Mixed Covariance Analysis for the analysis of current highlatitude spring wheat genotypes. Peltonen-Sainio et al. (2009) studied spring wheat yield trends and sustainability in Finland using the MTT Agrifood Research Finland 1970-2005 official variety trial data. The Mixed structural covariance technique was used to divide the yield trends in variety trials into two intracultivar G×E covariance components: genetic improvements and environmental changes. According to Peltonen-Sainio et al. (2009) the yield trends of future wheat genotypes will constantly increase during global climate change (IPCC 2007) because of the increasing demand for food and biofuel production. Cereal theoretical maximum yield capacity is limited by environmental and vegetation stresses during growing season (Passioura 2006, Rajala et al. 2009). These stress factors result in reduced non-potential baseline yield levels $\left(\mathrm{y}_{\mathrm{b}}, \mathrm{kg} \mathrm{ha}^{-1}\right)$ for cereals in actual non-optimal field growing conditions. In this study the Mixed Analysis was applied for evaluating the factors affecting non-potential baseline yield levels $\left(\mathrm{y}_{\mathrm{b}}\right)$ between HiL and MidE wheat genotypes.

The Path coefficient analysis, using standardized regression coefficients, has been widely applied for structural analysis in population genetics to detect underlying covariance and indirect, interacting factors (Dewey and Lu 1959, Li 1974). In this study Path coefficient analysis was applied to identify significant direct and indirect effect factors affecting yield potential with HiL ideotypes.

In Finland, spring wheat production in high-latitude northern agriculture regions is limited by a short growing season, which reduces the light intensity and temperature available for crop growth (Saarikko 1999). Kontturi (1979) reported a photoperiodical threshold daylength of 18 hours for high-latitude genotypes adapted to Finnish long day growing conditions. Daylengths below the threshold delay vegetative phase from sowing to heading. In generative phase from heading to full maturity, the thermal time controls the phenological development.

The ideotype analysis for Finnish growing conditions with G×E interactions has been reviewed by Peltonen-Sainio (1992) and Mäkelä et al. (1996) for spring wheat, barley and oat genotypes grown under long day growing conditions. Aula and Talvitie (1995) studied yield production with high latitude rye (Secale cereale L.) and wheat genotypes using organic and conventional cultivation practices.

Currently only few crop modeling results are available for the identification of the most important factors affecting wheat non-potential baseline yield levels currently and in the 2050-2100 period with elevated temperature and atmospheric $\mathrm{CO}_{2}$ levels in Finland (Saarikko 1999, Laurila 1995,2001). In Finland the FINSKEN climate change scenario (Saarikko et al. 1996, Saarikko 1999, Carter 2004) estimated that atmospheric $\mathrm{CO}_{2}$ concentration with 
seasonal variation will increase from the current mean ambient $377 \mathrm{ppm}$ to $523 \mathrm{ppm}$ and the mean temperature will increase by $2.4{ }^{\circ} \mathrm{C}$ by the year 2050 and respectively to $733 \mathrm{ppm}$ and by $+4.4{ }^{\circ} \mathrm{C}$ by the end of 2100 .

Previous Finnish crop simulation results (Laurila 1995, 2001), field and Open Top Chamber (OTC) crop physiological experimental results (Hakala 1998, Hakala et al. 2005) for a high-latitude spring wheat cultivar (cv. 'Polkka') indicated, that the concurrent elevated atmospheric $\mathrm{CO}_{2}$ concentration (700 ppm) and elevated diurnal temperature $\left(+3{ }^{\circ} \mathrm{C}\right)$ will increase the yield potential of the HiL wheat genotypes by $1-6 \%$ (by 9-13\% for a mid-European cv. 'Nandu') by 2100 in southern Finland. The sole elevated temperature effect had a decreasing effect on wheat yield potential by accelerating the cereal phenological development especially in the generative phase (Hakala 1998, Hakala et al. 2005).

The overall objective of the present study was the identification and evaluation of high-latitude (HiL, growing latitude $>60^{\circ} \mathrm{N}$ ) and mid-European (MidE, $<60^{\circ} \mathrm{N}$ ) ideotype profiles $\left(\mathrm{ItPrf}_{\mathrm{HiL}, \mathrm{MidE}}\right.$ ) adapted for future growing conditions with elevated $\mathrm{CO}_{2}$ and temperature levels in southern Finland by deriving generic HiL and MidE spring wheat genotypes validated in this modeling study.

The specific objectives of the present study consisted of following modeling and analysis procedures: (i) evaluating factors affecting non-potential baseline grain yield levels $\left(y_{b}\right)$ between HiL and MidE springs wheat genotypes in soil type, cultivation practices and decade of introduction to cultivation categories (ii) identifying the most important vegetation parameters and yield components affecting the yield capacity of HiL and MidE wheat ideotypes, (iii) evaluating the genotypexenvironmental (GXE) covariances (Eq. 1) and source-sink interactions affecting grain yield potential between high yielding wheat ideotypes, and finally (iv) assessing implications for future adaptation strategies in southern Finland using high yielding spring wheat ideotypes.

\section{Materials and methods}

\section{Data sources}

Table 1 illustrates different data sources applied in this study with different modeling phases (I-IV, Fig. 1), experimental years, Mixed structural categories for HiL and MidE genotypes (Table 2) and references for datasets. The definitions and abbreviations applied in this study are presented in Table 10 (Appendix 1). During modeling process different datasets were combined and consolidated for different analyses (Fig. 1).

Dataset I (Table 1) provided the primary field experimental data for HiL and MidE spring wheat modeling methods applied in this study. Dataset I was extracted from the 1978-2007 MTT Agricultural Research Centre Official variety trial data, containing yield data for spring wheat genotypes currently cultivated in Finland (Järvi et al. 1997, Kangas et al. 2006, 2008).

Dataset II provided averaged yield estimates for MidE wheat genotypes using the European wheat genotype database (ECP/GR). Dataset III provided the baseline yield $\left(\mathrm{y}_{\mathrm{b}} \mathrm{kg} \mathrm{ha}^{-1}\right)$ estimates for HiL and MidE spring wheat cultivars using the Finnish agricultural remote sensing large area results in 1996-2006 (Laurila et al. 2010a, 2010b). Experimental sites were located in southern Finland and in Etelä-Pohjanmaa Agricultural Advisory Centre in growing zones I-IV. Baseline yield estimates $\left(\mathrm{y}_{\mathrm{b}}\right)$ for spring what genotypes were compared with averaged MTT official variety trial results and with annual Ministry of Agriculture Finland stratum sampling estimates for crop inventory. With datasets IV and V, crop physiological experiments and simulation studies were used to evaluate the effects of elevated atmospheric $\mathrm{CO}_{2}$ and elevated temperature levels on yield potential and phenological development of $\mathrm{HiL}$ and MidE spring wheat genotypes. The SILMU I (The Finnish Research Program for Climate Change, 1992-1994) data was extracted from Open Top Chamber experiments (Hakala 1998, Hakala et al. 1999, Laurila 2001). The SILMU II data was extracted from greenhouse and pot experiments (Saarikko et al. 1996, Saarikko 1999). Dataset VI provided the averaged yield levels for rye and HiL spring wheat genotypes with organic and ecological cultivation practices (1989-1993) from the MTT Satakunta Research station (Aula and Talvitie 1995). With dataset VII, the HiL and MidE spring wheat data from the Pöytyä and Helsinki University experimental sites was used to evaluate the Cultivation value model (Peltonen 2010). Datasets VIII (Rajala et al. 2009) and IX (unpublished data) provided detailed morphological, yield quality and yield component data for HiL spring wheat genotypes. 
Table 1. Spring wheat data sources and field experiments.

\begin{tabular}{|c|c|c|c|}
\hline $\begin{array}{l}\text { Dataset } \\
\text { (Modeling } \\
\text { phase, Fig. 1) }\end{array}$ & Dataset & $\begin{array}{l}\text { Experiment } \\
\text { years, Mixed } \\
\text { categories }^{3 /}\end{array}$ & References \\
\hline $\mathrm{I},(\mathrm{I})$ & $\begin{array}{l}\text { Spring wheat official variety trial data (MTT } \\
\text { Agrifood Research Finland), } \\
\text { Estimation of Cultivation value }\left(\mathrm{C}_{\mathrm{Val}}\right)\end{array}$ & $\begin{array}{l}\text { 1978-2007, } \\
\text { (HiL/MidE) } \\
\text { Old }_{, 70,80}\end{array}$ & $\begin{array}{l}\text { Järvi et al. 1997, Kangas et al. 2006, 2008, } \\
\text { Peltonen } 2010\end{array}$ \\
\hline II, (I) & $\begin{array}{l}\text { The European Wheat Database (European } \\
\text { Cooperative Programme for Crop Genetic } \\
\text { Resources Networks ECP/GR }\end{array}$ & $\begin{array}{l}\text { 1978-2010, } \\
\text { (HiL/MidE) } \\
\text { Old }_{, 70,80}\end{array}$ & http://genbank.vurv.cz/ewdb/ \\
\hline III , (l) & $\begin{array}{l}\text { Finnish agricultural remote sensing field } \\
\text { experiments 1996- } 2006 \text { with actual field } \\
\text { condition measurements btw. MTT official } \\
\text { variety trials vs. Ministry of Agriculture Finland } \\
\text { stratum estimates }\end{array}$ & $\begin{array}{l}\text { 1996-2006, } \\
\text { (HiL/MidE) } \\
\text { Old }_{80,} \mathrm{New}_{90}\end{array}$ & Laurila et al. 2010a, 2010b \\
\hline $\mathrm{IV},(\mathrm{I})$ & $\begin{array}{l}\text { SILMU I Experimental data from Open Top } \\
\text { Chamber experiments with elevated } \mathrm{CO}_{2} \text { and } \\
\text { temperature levels }{ }^{2)}\end{array}$ & $\begin{array}{l}\text { 1992-1994, } \\
\text { (HiL/MidE) } \\
\text { Old }_{80,} \mathrm{New}_{90}\end{array}$ & $\begin{array}{l}\text { Hakala 1998, Hakala et al. 1999, 2005, } \\
\text { Laurila 1995, } 2001\end{array}$ \\
\hline $\mathrm{V},(\mathrm{I})$ & $\begin{array}{l}\text { SILMU II Experimental data with field, } \\
\text { greenhouse and pot experiments. }\end{array}$ & $\begin{array}{l}\text { 1994-1996 } \\
\text { (HiL/MidE) } \\
\text { Old }_{80,} \text { New }_{90}\end{array}$ & $\begin{array}{l}\text { Saarikko et al. 1996, Saarikko 1999. Data } \\
\text { prov. by Dr. R. Saarikko }\end{array}$ \\
\hline $\mathrm{VI},(\mathrm{l})$ & $\begin{array}{l}\text { The rye and spring wheat experiments for } \\
\text { organic and ecological cultivation, MTT } \\
\text { Agrifood Res. Finland (Ylistaro, Satakunta) }\end{array}$ & $\begin{array}{l}\text { 1989-1993, } \\
\text { (HiL) } \\
\text { Old }_{, 70,80,} \mathrm{New}_{90}\end{array}$ & Aula and Talvitie 1995 \\
\hline VII ,(II) & Cultivation value estimation dataset & $\begin{array}{l}\text { 2009-2010, } \\
\text { (HiL/MidE) } \\
\text { Old }_{80,} \text { New }_{90}\end{array}$ & $\begin{array}{l}\text { Peltonen 2010, } \\
\text { Dr. Jari Peltonen, Helsinki Univ. Exp. site and } \\
\text { Pöytyä Exp. Site }\end{array}$ \\
\hline VIII, ,(III) & $\begin{array}{l}\text { Spring wheat yield component and quality } \\
\text { factor data. }\end{array}$ & $\begin{array}{l}\text { 1996-1998, } \\
\text { (HiL) } \\
\text { Old }_{, 70,80} \mathrm{New}_{90}\end{array}$ & $\begin{array}{l}\text { Rajala et al. 2009. Data provided by Dr. Ari } \\
\text { Rajala (MTT Agrifood Res. Finland) }\end{array}$ \\
\hline IX ,(III) & $\begin{array}{l}\text { Spring wheat data containing yield component } \\
\text { and morphological characteristics for } 20 \text { spring } \\
\text { wheat genotypes (Helsinki Univ., Dept of Crop } \\
\text { Husbandry) }\end{array}$ & $\begin{array}{l}\text { 1988, } \\
\mathrm{HiL}_{\text {old }, 70,80}\end{array}$ & $\begin{array}{l}\text { Unpub. data provided by Dr. R. Karjalainen } \\
\text { and Ms. Sci. T. Kangasmäki (MTT Agrifood } \\
\text { Res. Finland). }\end{array}$ \\
\hline
\end{tabular}

1) Modeling phases (I-IV) are described in Fig. 1. ${ }^{2)}$ The Finnish Program for Climate Change (SILMU 1992-1996, Kuusisto et al. 1996). ${ }^{3)}$ Mixed categories in Table 2.

\section{Modeling process and system analysis}

The detailed modeling process and system analysis (Ritchey 1996, IIASA 2010) applied in this study, is illustrated in Figure 1 describing the analysis methodology in phases I-IV, each phase using different experimental datasets (I-IX, Table 1). The detailed modeling process consisted of following phases.

1. In phase la1 previous crop modeling results (Laurila 1995, Laurila 2001) with the CERES-Wheat/DSSAT dynamic crop model (Ritchie \& Otter 1985, Jones et al. 2003) were used to calibrate and define the genetic coefficients (PHINT, P1V, P1D, P5, G1,G2,G3) for generic HiL (using cv. 'Polkka') and MidE (using cv. 'Nandu') genotypes using the MTT Agrifood Research Finland Official Variety Trial dataset 1978-2007 (Dataset I, Table 1). Genetic coefficients for generic spring wheat genotypes were used in defining the future HiL and MidE ideotype profiles. The CERES-Wheat genetic coefficients controlling spring wheat phenological development (PHINT with leaf appearance rate and phyllochron interval, P1V affecting vernalization, P1D affecting photoperiodism and P5 affecting grain filling duration) and yield components (G1 defining the grains per ear component, G2 defining the 1000 seed weight and G3 defining spike number with lateral tiller production) are given in Table 10 (Appendix 1).

2. In phases la2-Ic the HiL vs. MidE structural contrast categories for spring wheat genotypes were defined and analyzed by using the combined I-VI dataset (1978-2010, Table 2).

3. In phase Id the latitudal contrasts (HiL $>60^{\circ} \mathrm{N}$ lat. vs. MidE genotypes $<60^{\circ} \mathrm{N}$ lat.) with corresponding baseline yield estimates $\left(\mathrm{y}_{\mathrm{b}}, \mathrm{kg} \mathrm{ha}^{-1}\right)$ were estimated by using datasets I-VI (Tables 3-5). 
4. In phase le the decade of introduction to cultivation contrast $\left(\mathrm{Old}_{70}\right.$ vs. $\mathrm{Old}_{80} \mathrm{vs}$. New $\left.{ }_{90}\right)$ with baseline yield estimates $\left(\mathrm{y}_{\mathrm{b}}\right)$ were estimated by using datasets I-VI (Tables 3-5).

5. In phase If the cultivation practices contrast (conventional vs. organic cultivation) with baseline yield estimates $\left(\mathrm{y}_{\mathrm{b}}\right)$ were estimated (dataset $\mathrm{VI}$, Tables 3, 4).

6. In phase Ig the soil type contrast (coarse type soils vs. fine type soils vs. organic type soils) with baseline yield estimates $\left(\mathrm{y}_{\mathrm{b}}\right)$ were estimated (datasets I-VI, Tables 3, 4).

7. In phases Ila-IIf the Cultivation Value model (Weizensorten und Backqualität 1990, Peltonen et al. 1993) using dataset VII was used to estimate the total cultivation scoring value profiles $\left(\mathrm{C}_{\text {ValTot }}\right)$ for HiL and MidE high yielding generic wheat genotypes in Finland (Table 5).

8. In phases IIIa-IIIb Principal Component Analysis (PCA) and correlation analyses were used with datasets VIIIIX to identify significant PCA factor loadings and correlations for vegetation parameters $\left(\mathrm{p}_{\mathrm{v}}\right)$ and yield components $\left(p_{\mathrm{y}}\right)$ with HiL ideotypes (Tables 6-8).

9. Phases IIIc-IIle yielded, using Path coefficient analysis (Wright 1923, Dewey and Lu 1959, Li 1974) and datasets VIII-IX, significant direct and indirect effect factors affecting yield potential with HiL ideotypes. In Pathmodels (I-IV, Table 6) significant direct effect factors were expressed as Path-coefficients for vegetation parameters ( $p_{v}$, Table 7$)$ and yield components $\left(p_{v}\right.$ Table 8$)$ respectively. Correlation coefficients were used to measure indirect effects. Coefficient of determination ( $\left.R^{2}, E q .7\right)$ and error residual factors (U, Eq. 6) were used to evaluate Path coefficient models I-IV.

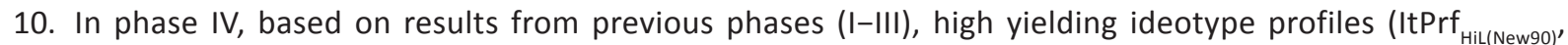

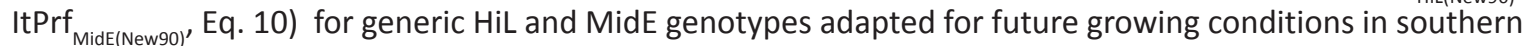
Finland were calibrated and validated. 


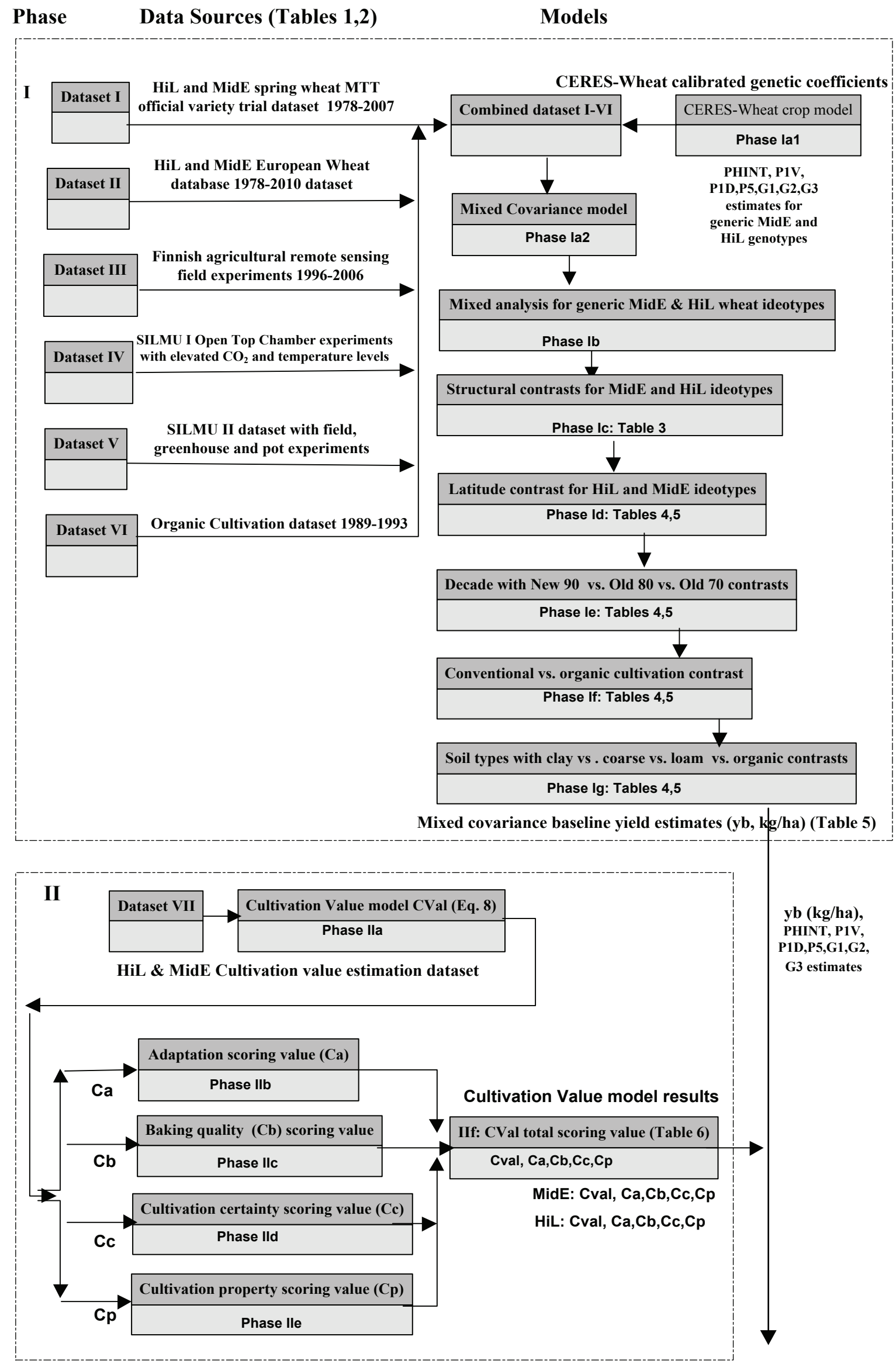




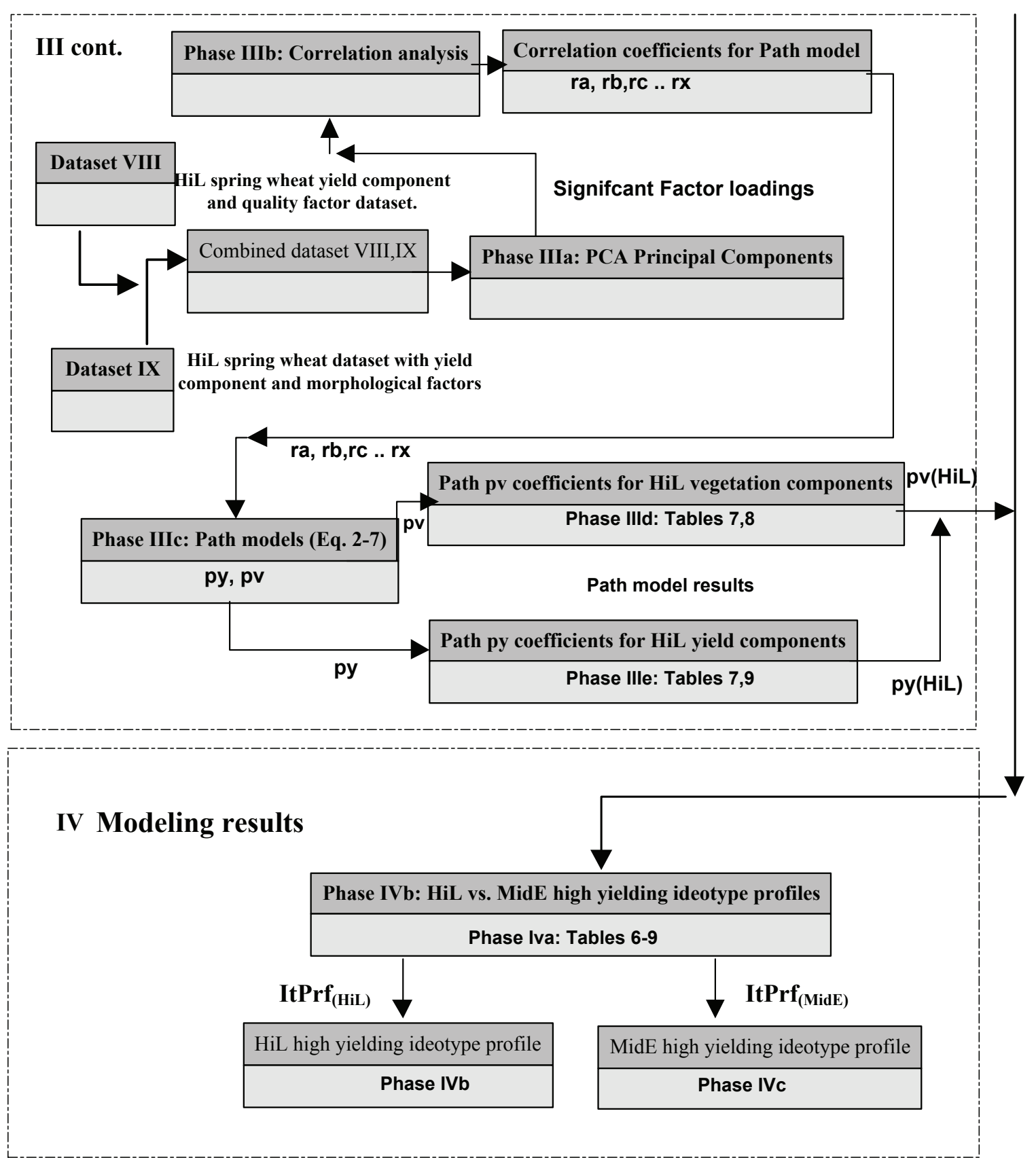

Fig. 1. Modeling process diagram with phases I-IV for identifying generic ItPrf(HiL) and ItPrf(MidE) ideotype profiles, data sources are given in Table 1 (Ritchey 1996, IIASA 2010).

\section{Soil type variation in the experimental sites}

The detailed soil classifications in experimental areas in southern Finland (experimental datasets I-IX, Table 1) with corresponding growing zones (I-IV) is reviewed by Laurila et al. (2010a,b). The Ylistaro, Lapua, Ilmajoki and Seinäjoki experimental sites were located near the Gulf of Bothnia on sandy clay type soils. Respectively Helsinki, Porvoo and Kirkkonummi experimental sites were located close to the Baltic Sea. Jokioinen and Mellilä sites were located mainly on clay type soils. Currently a growing zone classification of four growing zones (I-IV) is applied for the high-latitude genotypes (HiL) currently cultivated in southern Finland: Zone 1 - Southern and SW-Finland (Lat. $<61^{\circ} \mathrm{N}$ ), Zone 2 - Southern Finland (Lat: $61^{\circ} \mathrm{N}<62^{\circ} \mathrm{N}$ ), Zone 3 - Southern Finland (Lat: $<62^{\circ} \mathrm{N}$ ), Zones 3-4, Northern Finland (Lat: $>62^{\circ} \mathrm{N}$ ). The zonal classification is based on Effective Temperature Sum (ETS) expressed as cumulative degree-days [dd] with a threshold temperature (Tb) of $5{ }^{\circ} \mathrm{C}$ (Kontturi 1979, Saarikko 1999). 


\section{Statistical analysis}

SAS ${ }^{\mathrm{TM}}$ statistical software (SAS, 1990) was used for Mixed Structural Covariance analysis (Phase I, Fig. 1), Cultivation value (Cval) model (Phase II), Principal component (PCA), correlation and Path coefficient analysis (Phase III, SAS REG and GLM procedures). Least squares (LSQ) algorithm was applied in the linear model fitting with SAS REG and GLM (General Linear Model) procedures. Mixed, Cval and Path models were used to detect spring wheat inter- and intracultivar GxE covariances and underlying variables interacting with wheat grain yield potential (Eq. 1, Falconer and Mackay 1996, Boote et al. 2001).

$$
\mathrm{V} p=\mathrm{Vg}+\mathrm{Ve}+2 \operatorname{Cov}(g e)
$$

where $\mathrm{V}_{p}$ - phenotype variation, $\mathrm{V}_{g}$ - genotype variation, $\mathrm{V}_{e}$ - environmental variation, $\mathrm{Cov}_{(g e)}$ - genotype $\mathrm{G} \times \mathrm{E}$ environmental covariance variation in broad sense

According to Falconer and Mackay (1996) the phenotypic variance $\left(V_{p}\right)$ of a plant genotype can be divided into genetic $\left(\mathrm{V}_{\mathrm{g}}\right)$ and environmental variance $\left(\mathrm{V}_{\mathrm{g}}\right)$. The ratio $\mathrm{V}_{\mathrm{g}} / \mathrm{V}_{\mathrm{p}}$ is defined as a degree of genetic determination or heritability in broad sense (Eq.1). The environmental sensitivity of a genotype, measuring the interaction between genetic and environmental variances can be estimated by including a covariance component $\operatorname{Cov}_{\text {(ge). }}$

The SAS Univariate procedure was used with the experimental data (Table 1) to test the normal distribution of both the dependent (non-potential grain yield, $\mathrm{y}_{\mathrm{b}} \mathrm{kg} \mathrm{ha}^{-1}$ ) and independent yield and vegetation components by using Kolmogorov and Shapiro-Wilk test statistics (data not shown).

\section{Mixed Structural Covariance analysis}

Mixed structural covariance analysis using SAS Mixed procedure (Littel et al. 1996) was used in this study (Phase I, Fig. 1) to model ideotype baseline yield levels $\left(y_{b}, \mathrm{~kg} \mathrm{ha}^{-1}\right)$ for different HiL and MidE wheat genotypes. The baseline grain yield $\left(\mathrm{y}_{\mathrm{b}}\right)$ was used as a response variable in the Mixed-model. Datasets I-VI (Table 1) containing long time series (1978-2010) were used in Mixed analysis to estimate baseline yield estimates $\left(\mathrm{y}_{\mathrm{b}}\right)$ on (i) structural contrast category levels (Tables 2,4) and (ii) on genotype level (Tables 3,5).

Table 2. Structural contrast categories of wheat genotypes (Mixed-model, Littel et al. 1996)

\begin{tabular}{|c|c|}
\hline Category & Genotype structural contrast categories (Mixed-model) \\
\hline $\mathrm{i}$ & 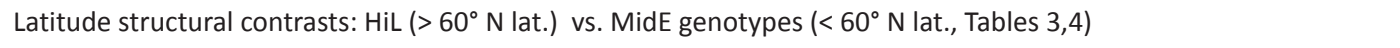 \\
\hline ii & $\begin{array}{l}\text { Decade of introduction to cultivation structural contrasts: }(\mathrm{HiL} / \mathrm{MidE})_{\mathrm{New} 90} \text { vs. }(\mathrm{HiL} / \mathrm{MidE})_{\mathrm{Old} 80} \text { vs. }(\mathrm{HiL} / \mathrm{MidE})_{\mathrm{Old70}}(\mathrm{Tables} \\
3,4)\end{array}$ \\
\hline iii & $\begin{array}{l}\text { Cultivation practices structural contrasts: conventional vs. organic practices (including ecological cultivation practices } \\
\text { applied in Finland, Table 4) }\end{array}$ \\
\hline iv & Soil structural contrasts: coarse type soils vs. fine type soils vs. vs. organic type soils (Table 4) \\
\hline
\end{tabular}

In Table 2, Mixed structural contrast categories applied in this study for wheat genotypes are displayed: (i) the latitude structural contrast comparison between HiL vs. MidE latitudes, (ii) the decade of introduction to cultivation contrast between genotypes introduced for cultivation before 1970 (HiL/MidE) old70 $_{1}$ vs. 1980 (HiL/MidE) old80 $_{1}$ vs. after 1990 (HiL/MidE) ${ }_{\text {New9o, }}$ (iii) cultivation practices contrast between conventional vs. organic cultivation (including ecological cultivation practices applied in Finland), (iv) the different soil type contrast comparison (coarse, fine and organic soil types).

The spring wheat genotypes evaluated in the Mixed-model analysis are displayed in Table 3.

High-latitude genotypes from Finland, Sweden and Norway and mid-European genotypes from Netherlands, Germany, UK, Tscheck and Serbia were classified into cultivation contrast categories based on cultivation latitude (HiL vs. MidE) and decade of introduction to cultivation $(1970,1980,1990)$. 
Table 3. Spring wheat genotypes in (I) latitude and (II) decade of introduction to cultivation contrast categories (Littel et al. 1996). ${ }^{1)}$

\begin{tabular}{|c|c|c|}
\hline \multicolumn{2}{|l|}{$\begin{array}{l}\text { Mixed Structural } \\
\text { Contrast category }\end{array}$} & \multirow[t]{2}{*}{ Genotype, origin, breeder reference, year of introduction to cultivation } \\
\hline I Latitude & II Decade & \\
\hline \multirow{3}{*}{$\begin{array}{l}\text { High-latitude } \\
\text { genotypes } \\
\text { (>60 } \mathrm{N} \text { lat.) }\end{array}$} & $\mathrm{HiL}_{\text {Old70 }}$ & $\begin{array}{l}\text { Finland: Apu (Ref.), Heta, Kruunu ( } \mathrm{C}_{\text {val }} \text { Ref.), Ruso, Sebastian, Taava, Tähti, Tapio, Ulla } \\
\text { Sweden: Drabant (Ref.) }\end{array}$ \\
\hline & $\mathrm{HiL}_{\mathrm{Old} 80}$ & $\begin{array}{l}\text { Finland: Aino (Ref. Bor }{ }^{3)} \text { ), Luja } \\
\text { Sweden: Polkka (Ref., SW), Dragon, Kadett, } \\
\text { Norway: Reno (Ref. Norsk Kornforedling 1987), Runar, Norrona }\end{array}$ \\
\hline & $\mathrm{HiL}_{\text {New90 }}$ & $\begin{array}{l}\text { Finland: Mahti (Ref., Bor }{ }^{3} \text {, 1994), Anniina (Boreal), Kadrilj, Kruunu (Bor }{ }^{3)} \text { ), Laari, Manu, } \\
\text { Marble (Boreal), Wellamo (Boreal) } \\
\text { Norway: Bastian (Ref.) } \\
\text { Sweden: Tjalve (Ref., SW 1993), Zebra (SW), Bjarne (SW), Landjet, Sport, Vinjett, Satu }\end{array}$ \\
\hline \multirow{2}{*}{$\begin{array}{l}\text { Mid-European } \\
\text { Genotypes } \\
\left(<60^{\circ} \mathrm{N} \text { lat }\right)\end{array}$} & MidE $_{\text {Old80 }}$ & $\begin{array}{l}\text { Netherlands: Matador (Ref., Dept. of Plant Brd. Agric. Univ., Wageningen), Pasteur ( Zelder } \\
\text { B.V) }\end{array}$ \\
\hline & MidE $_{\text {New90 }}$ & $\begin{array}{l}\text { Germany: Nandu (Ref.) }{ }^{2)} \text {, Amaretto, Attis, Epos, Mieka, Monsun, Munk, Picolo(Saaten } \\
\text { Union), Triso, Sella, Trappe (DEU060, Bor }{ }^{3)} \text { ) } \\
\text { UK: Azurite (www.hgca.com) } \\
\text { Tscheck Republic.: Quarna (Ref.), Bombona } \\
\text { Netherlands: Jondolar (Ref.) } \\
\text { Serbia: Marina (Ref.) }\end{array}$ \\
\hline
\end{tabular}

1) Ref. - Reference genotype/cultivar in the Mixed analysis (Table 10). Countries: NI.- Netherlands, ${ }^{2)}$ Saatzuchtwirtschaft F. von LochowPetkus $\mathrm{GmbH}^{3)}$ Bor - Boreal plant breeding, Finland, SW - Svalöf-Weibull

\section{Correlation, PCA and Path analyses for High-latitude (HiL) vegetation and yield components}

After the Mixed covariance and Cultivation value analysis, the combined VIII-IX dataset was analyzed with correlation, PCA (Principal Component Analysis) and Path coefficient analysis (phase IIla, Fig. 1) to identify significant vegetation $\left(\mathrm{p}_{\mathrm{v}}\right)$ and yield $\left(\mathrm{p}_{\mathrm{y}}\right)$ components affecting $\mathrm{HiL}_{\mathrm{Old} 70}, \mathrm{HiL} \mathrm{Old80}$ and $\mathrm{HiL}_{\text {New90 }}$ genotype yield potential (Tables 2,3). Correlation coefficients were used in Path-models (I-IV, Eq. 5) to construct standardized Path regression equations (Table 6).

\section{Path analysis}

The Path coefficient theory was originally presented by Wright (1923) and later revised for wheat seed production analysis by Dewey and Lu (1959). Li (1974) applied Path coefficient analysis for population genetics and Falconer \& Mackay (1996) for quantitative genetics (Eq. 1). Later on, Path coefficient analysis was applied in yield component analysis for spring wheat mutants (Siddiqui et al. 1980) and for spring wheat genotypes (Reynolds et al. 2007).

In this study, Path coefficient analysis was calculated according to methodology presented by Dewey and Lu (1959) and Li (1974). Path-coefficients, which are standardized regression-coefficients, can be derived from general linear regression equation (Eq. 2). Path-coefficients were calculated using the SAS stepwise regression (REG) and GLM (General Linear Model) procedures (SAS 1990).

$\mathrm{Y}=\mathrm{b} 0+\mathrm{b} 1 * \mathrm{~A}+\mathrm{b} 2 * \mathrm{~B}+\ldots \mathrm{bx} * \mathrm{X}+\varepsilon$

where $Y=$ dependent variable, $\left(\mathrm{V}_{\mathrm{b}}\right.$, baseline grain yield, $\mathrm{kg} \mathrm{ha}^{-1}, 15 \%$ moisture content $), \mathrm{b}_{0}=$ model intercept, $b_{1}, b_{2} b_{x}=$ regression coefficients for independent variables $A, B$ and $X, \varepsilon=$ error residual variation $(=0)$

Equation 2 can be standardized by using standard deviations $\left(s_{y^{\prime}} s_{a^{\prime}}, s_{b}, s_{x}\right)$ for dependent $(Y)$ and independent variables (A, B..X) (Eq. 3).

$\mathrm{Y}=\mathrm{b} 0+[\mathrm{b} 1 *(\mathrm{Sa} / \mathrm{Sy})) * \mathrm{~A}]+[\mathrm{b} 2 *(\mathrm{Sb} / \mathrm{Sy})) * \mathrm{~B}]+\ldots[\mathrm{bx} *(\mathrm{Sx} / \mathrm{Sy})) * \mathrm{X}$

where $s_{y^{\prime}} s_{a^{\prime}} s_{b^{\prime}}, s_{x}=$ standard deviations (SD) for variables $Y, A, B, X$ 
Equation 3 can be simplified into Equation 4 using Path-coefficients, which measure the direct effects on dependent variable $(\mathrm{Y})$.

$\mathrm{Y}=\mathrm{b} 0+\mathrm{pa} * \mathrm{~A}+\mathrm{pb} * \mathrm{~B}+\ldots \mathrm{px} * \mathrm{X}$

where $\mathrm{p}_{\mathrm{a},} \mathrm{p}_{\mathrm{b},} \mathrm{p}_{\mathrm{x}=}$ Path-coefficients, $\mathrm{p}_{\mathrm{a}}=\mathrm{b}_{1} *\left(\mathrm{~S}_{\mathrm{a}} / \mathrm{S}_{\mathrm{y}}\right), \mathrm{p}_{\mathrm{b}}=\mathrm{b}_{1} *\left(\mathrm{~S}_{\mathrm{b}} / \mathrm{S}_{\mathrm{y}}\right), \mathrm{p}_{\mathrm{x}=} \mathrm{b}_{\mathrm{x}} *\left(\mathrm{~S}_{\mathrm{x}} / \mathrm{S}_{\mathrm{y}}\right)$

The standardized Path-model (Eq. 5) can be derived from Equation 4 by adding correlation coefficients $\left(r_{i}\right)$ between independent and dependent variables (Phase III, Fig. 1). Correlation coefficients measure indirect effects on dependent variable $(Y)$. The standardized Path-model equations for high-latitude ideotypes are presented in Table 6.

$$
\mathrm{Y}=\mathrm{pa} * \mathrm{ra} * \mathrm{~A}+\mathrm{pb} * \mathrm{rb} * \mathrm{~B} . \mathrm{pc} * \mathrm{rc} * \mathrm{X}
$$

where $r_{a}, r_{b}, r_{x}=$ correlation coefficients for dependent variables $A, B, X$

The residual-factor $(\mathrm{U})$ estimates the unexplained variance estimated by the Path model (Eq. 6). U-factor is calculated by summing Path-coefficients $\left(p_{i}\right)$ and subtracting the sum from 1 according to Equation 6 . The U-factors for HiL genotypes are presented in Table 6.

$$
\mathrm{U}=1-\sum_{(\mathrm{i}=1)}^{\mathrm{k}}(\mathrm{pi})
$$

where $U=$ residual factor, ${ }^{k} \Sigma_{(b=1)}(p i)=$ Sum of Path-coefficients $p_{i}$, index $i=1 . . k$.

The total variance, explained by the Path-model, can be measured as $R^{2}(Y)$-values (R-square, coefficient of determination) for the dependent variable. $R^{2}$ values (Eq. 7) can be derived by summing the multiplication product of correlation and Path-coefficients for independent variables (A,B..X). $R^{2}$ estimates for HiL genotypes are presented in Table 6.

$$
\mathrm{R}^{2}(\mathrm{Y})=\sum_{(\mathrm{i}=1)}^{\mathrm{n}}[(\mathrm{pa} * \mathrm{ra})+(\mathrm{pb} * \mathrm{rb}) \ldots(\mathrm{px} * \mathrm{rx})]
$$

where $R_{i}=$ correlation coefficient, $p_{i}=$ path-coefficient, $A, B . . X=$ independent variables, index $i=1 . . n$

\section{Wheat Cultivation value model}

A regression based German ranking and scoring Cultivation value model (Weizensorten und Backqualität 1990), previously applied for Finnish spring wheat varieties (Peltonen et al. 1993, Peltonen 2010) was applied in this study (Phase II, Fig. 1) to estimate the cultivation values of spring wheat genotypes currently cultivated in southern Finland in growing zones I-III (Dataset VII, Table 1). The cultivation value was expressed as a total scoring value $\left(C_{\text {val- }}\right.$ ${ }_{\text {Tot }}$ ) in current highest yielding wheat genotypes, which are cultivated in growing zones I-III in southern Finland (Eq. 8). Cv. 'Kruunu' (HiL old70 $_{1}$ ) was used as a control and reference genotype (Ref.) in the model.

$$
\text { CValTot }=C a+C c+C p+C b
$$

where $C_{\text {ValTot }}$ - Cultivation total scoring value of a genotype in growing zones I-III, $C_{a}$ - Adaptation plasticity scoring value inside cultivation zone (I-III), $C_{c}$ - Cultivation certainty scoring value, $C_{p}$ - Cultivation property scoring value, $C_{b}$ - Baking quality scoring value.

In the Cultivation value model, a three class classification was applied for wheat genotypes (i) Elite wheat class, (ii) Quality wheat class and (iii) Other wheat class (Peltonen et al. 1993, Table 5). The genotypes used in the scoring model were 'Quarna' (MidE ${ }_{\text {New90 }}$ ), 'Amaretto' (MidE ${ }_{\text {New9o }}$ ), 'Epos' (MidE ${ }_{\text {New9o }}$ ), 'Wellamo' (HiL New90 ), 'Zebra'

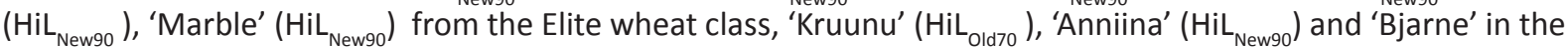
Quality wheat class and 'Trappe' (MidE ${ }_{\text {New90 }}$ ) in the Other wheat class (Table 1, Peltonen 2010). The corresponding genotypes in latitudal and decade of introduction to cultivation contrasts are presented in Table 3. 
The adaptation plasticity scoring value $\left(\mathrm{C}_{\mathrm{a}}\right)$ in growing zones I-III consisted of growing days $(\mathrm{d})$ and relative yield in growing zones I-III (cv. 'Kruunu' as a control = 100). The cultivation certainty scoring value $\left(C_{c}\right)$ consisted of grain yield $\left(\mathrm{kg} \mathrm{ha}^{-1}\right)$ and relative yield expressed as a three category classification: (i) the low final grain yield (median $4 \mathrm{t} \mathrm{ha}^{-1}$ ), (ii) the medium final grain yield (median $5 \mathrm{t} \mathrm{ha}^{-1}$ ), and (iii) the high final grain yield (median $6 \mathrm{t} \mathrm{ha}^{-1}$ ). The cultivation property scoring value $\left(C_{p}\right)$ consisted of grain yield accumulation/growing day ratio $\left(\mathrm{kg} \mathrm{DM} \mathrm{d}^{-1}\right)$, the nitrogen amount in grains $\left(\mathrm{N} \mathrm{kg} \mathrm{ha}^{-1}\right)$, denoting the efficiency of a genotype to utilize nitrogen fertilization, the 1000 kernel weight $(\mathrm{g})$, the grain protein content (\%) and the falling number reduction (s) with late harvest. The baking quality scoring value $\left(\mathrm{C}_{\mathrm{b}}\right)$ consisted of the flour volume yield $(\%)$, the flour water retention capacity (\%), the falling number (s), the Farinograph dough water absorption (\%) and the bread loaf volume (ml).

\section{CERES-Wheat dynamic crop model with calibrated genetic coefficients}

The calibrated CERES-Wheat genetic coefficients (Ritchie \& Otter 1985, Jones et al. 2003) were used in defining the optimized ideotype profiles $\left(\right.$ ItPrf $_{\text {HiL,New9o }}$, ItPrf ${ }_{\text {MidE,New90 }}$ ) for future generic HiL (using cv. 'Polkka' as a reference cultivar, ref.) and MidE (cv. 'Nandu', ref.) genotypes in the New ${ }_{90}$ Mixed contrast category (Laurila 1995, 2001). The CERES-Wheat genetic coefficients controlling both spring wheat phenological development (PHINT with leaf appearance rate and phyllochron interval [dd] , P1V affecting vernalization, P1D affecting photoperiodism and P5 affecting grain filling duration) and yield components (G1 - the grains per ear component, G2 - the 1000 seed weight and G3 - spike number with lateral tiller production) are given in Table 10.

The RMSD (Root Mean Square Difference, Eq. 9) algorithm was used to calibrate both the CERES-Wheat genetic coefficients controlling spring wheat phenological development and yield components for generic HiL and MidE genotypes in Finland (Laurila 1995, Laurila 2001). The RMSD minimized the difference $\left(\mathrm{RMSD}_{\mathrm{YLD}}, \mathrm{t}\right.$ ha $\left.{ }^{-1}\right)$ between the observed and modeled baseline yield levels $\left(\mathrm{y}_{\mathrm{b}}\right)$ and phenological anthesis $\left(\mathrm{RMSD}_{\mathrm{ANTH}}\right)$ and full maturity (RMS$D_{\text {FMAT }}$ ) development phases for generic HiL and MidE genotypes. Dataset I (Table 1, Fig. 1, Phase la1) derived from the MTT Agrifood Official Variety Trial dataset (1978-2007) for spring wheat genotypes was used in the calibration process (Kangas et al. 2006, 2008).

$$
R M S D=\sqrt[2]{\sum_{i=1}^{n} \frac{d^{2}}{n-1}}
$$

where $d$ - difference (observed - simulated) in days (DOY - Day of Year) from sowing to anthesis (RMSD $\left.{ }_{\text {ANTH }}\right)$ and sowing to full maturity $\left(\right.$ RMSD $_{\text {FMAT }}$ ) in the calibration of phenological coefficients (PHINT, P1V, P5) or $d$ is also the yield difference $\left(R_{M S D_{Y L D}}\right.$ observed-simulated, $t \mathrm{ha}^{-1}$ ) in the calibration of yield coefficient components (G1, G2 and G3). Parameter $\mathrm{n}$ is the number of experimental sites $\mathrm{x}$ years ( 35 total) in the MTT Agrifood Research Finland Official Variety Trial dataset (1978-2007).

\section{Results}

\section{Variation in vegetation, leaf area and dry weight components}

There was a large variation between HiL and MidE genotypes in datasets I-IX (Table 1) with vegetation, leaf area and dry weight components.Especially in dataset IX, the highest yielding HiL cv. 'Kadett' (HiL ${ }_{\text {old80 }}$ ) had also the highest number of side tillers in June before anthesis. The lowest yielding cv. 'Tähti' $\left(\mathrm{HiL}_{\mathrm{Old70}}\right)$ had the minimum number of leaves/main stem in June. There was a large variation between HiL genotypes both in June and July in flag leaf area, second highest leaf area, flag leaf dry weight, second highest leaf dry weight in the main tiller and above ground biomass. Flag leaf area in the main tiller varied between $1620 \mathrm{~mm}^{2}$ and $2145 \mathrm{~mm}^{2}$ in vegetative phase in June and later in July in generative phase between $1236 \mathrm{~mm}^{2}$ ('Luja', HiL $\mathrm{Old}_{00}$ ) and $2398 \mathrm{~mm}^{2}$. The second highest leaf area in the main tiller varied between $1204 \mathrm{~mm}^{2}$ (cv. 'Luja', HiL $\mathrm{Old80)}_{\text {) }}$ and $1579 \mathrm{~mm}^{2}$ (cv. 'Ulla', HiL $\mathrm{Old70}$ ) in June and in July between $1295 \mathrm{~mm}^{2}$ and $1876 \mathrm{~mm}^{2}$. Respectively the Leaf Area Index (LAI) with fully developed flag leaves reached the LAI maximum value ( $\mathrm{LAI}_{\max }$ ) ranging on average between 4 and 5 during pre-heading and anthesis. Peltonen-Sainio et al. (2005) marked the fully developed flag leaves as the $L_{7}$ leaf development phase.

The dry weights of flag leaves in the main tiller varied between $38.8 \mathrm{mg}$ (cv. 'Tapio', HiL $\mathrm{Old7}_{\mathrm{O}}$ ) and $68.6 \mathrm{mg}$ (cv. 'Ka$\mathrm{dett}^{\prime}, \mathrm{HiL}_{\mathrm{Old80}}$ ). The dry weights of the second leaves in the main tiller varied between $26.2 \mathrm{mg}$ and $37.6 \mathrm{mg}$ in the vegetative phase in June and between $27.4 \mathrm{mg}$ and $68.8 \mathrm{mg}$ in generative phase in July. The total above ground dry weights of plants varied between $288.6 \mathrm{mg}$ (cv. 'Drabant', HiL $\mathrm{old70}_{10}$ ) and $449.8 \mathrm{mg}$ (cv. 'Tapio', HiL old70 $_{\text {) }}$ ) in vegetative phase and between $964.9 \mathrm{mg}$ (cv. 'Line 48') and $1829 \mathrm{mg}$ (cv. 'Drabant', HiL ${ }_{\text {old70 }}$ ) in generative phase. 


\section{Mixed contrast category results for baseline yield $\left(\mathrm{y}_{\mathrm{b}}\right)$ estimations}

The modeled mean baseline yield $\left(y_{b}\right)$ for a generic genotype over all contrast categories was $4014 \mathrm{~kg} \mathrm{ha}^{-1}$ (SD 245 $\mathrm{kg} \mathrm{ha}^{-1}$, Table 4, Fig 1., Phase I). In the decade contrast category, the modeled baseline yield levels $\left(\mathrm{y}_{\mathrm{b}}\right)$ were 3880 $\mathrm{kg} \mathrm{ha}^{-1}$ for the $\mathrm{HiL}_{\text {Old70 }}$ and $4010 \mathrm{~kg} \mathrm{ha}^{-1}$ for the $\mathrm{HiL}_{\text {Old80 }}$ generic genotypes and $4340 \mathrm{~kg} \mathrm{ha}^{-1}$ for the MidE ${ }_{\text {old80 }}$ category. With genotypes introduced into cultivation in the 1990s (New90) the baseline yield levels were $4650 \mathrm{~kg} \mathrm{ha}^{-1}$ for HiL and $5060 \mathrm{~kg} \mathrm{ha}^{-1}$ for MidE genotypes.

The conventional vs. organic cultivation category results in cultivation practices contrast suggest (Dataset VI), that genotypes cultivated with conventional practices $\left(4269 \mathrm{~kg} \mathrm{ha}^{-1}\right.$ ) had ca. $600 \mathrm{~kg} \mathrm{ha}^{-1}$ higher yielding capacity compared with genotypes cultivated with organic methods $\left(3640 \mathrm{~kg} \mathrm{ha}^{-1}\right)$. The soil type contrast indicates, that clay type soils produced higher baseline yields $\left(4100 \mathrm{~kg} \mathrm{ha}^{-1}\right)$ when compared with coarse $\left(3850 \mathrm{~kg} \mathrm{ha}^{-1}\right)$ and loam soil types (3702 kg ha-1).

Table 4. Hierarchical Mixed-model baseline yield estimates $\left(\mathrm{V}_{\mathrm{b}}, \mathrm{kg} \mathrm{ha}^{-1}\right)$ in different contrast categories (I-III).

\begin{tabular}{|c|c|c|c|c|}
\hline $\begin{array}{l}\text { I Latitude } \\
\text { contrast }\end{array}$ & $\begin{array}{l}\text { Il Cultivation type, soil type, } \\
\text { decade of introduction contrast }\end{array}$ & III genotype contrast & $\begin{array}{l}\text { Baseline } \\
\text { Mixed } \\
\text { estimate } \\
\left(\mathrm{y}_{\mathrm{b}} \mathrm{kg} \mathrm{ha}^{-1}\right) \\
(\mathrm{SD})\end{array}$ & $\begin{array}{l}\text { Mixed } \\
\text { estimation } \\
\text { error } \\
\left(\mathrm{kg} \mathrm{ha}^{-1}\right) \\
\text { 1) }\end{array}$ \\
\hline \multirow{6}{*}{$\begin{array}{l}\text { MidE } \\
\& \\
\text { HiL }\end{array}$} & Average all ${ }^{2)}$ & Generic Ideotype mean & $4014(245)$ & 94.8 \\
\hline & \multirow[t]{3}{*}{ Cultivation type ${ }^{3)}$} & Generic Conventional & 4269 & 17.9 \\
\hline & & Generic Organic & 3640 & 52.5 \\
\hline & & Coarse soils & 3856 & 27.5 \\
\hline & \multirow[t]{3}{*}{ Soil type } & Silt \& Loam soils & 3702 & 120.5 \\
\hline & & Clay soils & 4101 & 41.0 \\
\hline \multirow{4}{*}{ MidE } & & Organic soils & 3640 & 52.5 \\
\hline & MidE $1980^{4)}$ & Old 80 & 4375 & 28.2 \\
\hline & MidE 1990 4) & New90 & 5057 & 108.5 \\
\hline & HiL 1970 & Old 70 & 3886 & 19.2 \\
\hline \multirow{2}{*}{ HiL } & HiL $1980^{3)}$ & Old 80 & 4014 & 35.4 \\
\hline & HiL 1990 4) & New90 & 4652 & 59.6 \\
\hline
\end{tabular}

1) All levels significant on $0.1 \%$ error level $(* * *) .{ }^{2)}$ Over all MidE and HiL contrast categories.

3) Organic and conventional dataset VI (Table 1, Aula and Talvitie 1995). ${ }^{4)}$ Includes dataset II.

\section{Mixed and Cultivation value modeling results for generic HiL and MidE genotype evaluation}

Mixed modeling results on genotype level (Table 5) using datasets I-VI (Fig 1., Phase I) imply a general higher baseline yield $\left(\mathrm{y}_{\mathrm{b}}\right)$ level for a generic MidE genotype (4922 kg ha-1, SD $283 \mathrm{~kg} \mathrm{ha}^{-1}$ ) vs. a generic HiL genotype

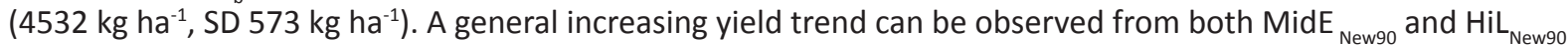
categories.

In the MidE ${ }_{\text {New90 }}$ contrast category genotypes 'Amaretto', 'Azurite', 'Bombona', 'Epos', 'Jondolar', 'Marina', 'Monsun', 'Picolo', 'Sella', 'Triso' exceeded the $5 \mathrm{t} \mathrm{ha}^{-1}$ baseline yield level and cv. 'Trappe' obtained the highest baseline grain yield level $\left(6.2 \mathrm{t} \mathrm{ha}^{-1}\right)$. In the $\mathrm{HiL}_{\text {new90 }}$ contrast category genotypes 'Kadrilj', 'Zebra' and 'Mahti' exceeded the $5 \mathrm{t} \mathrm{ha}^{-1}$ level.

\section{Generic HiL and MidE genotypes derived from the Mixed and Cultivation value analyses}

Table 5 presents the generic HiL and MidE genotypes with Mixed baseline yield estimates $\left(\mathrm{y}_{\mathrm{b}}, \mathrm{kg} \mathrm{ha}^{-1}\right)$ and Cultivation total scoring values ( $\mathrm{C}_{\text {ValTot' }}$ Eq. 8, Fig 1., Phase II, Table 1, dataset VII). 
Table 5. Mixed model baseline yield estimates $\left(\mathrm{y}_{\mathrm{b}}, \mathrm{kg} \mathrm{ha}^{-1}\right)$, observed mean yield values from datasets I-VII and Cultivation scoring value $\left(C_{\text {val }}\right)$ profiles on genotype level. ${ }^{1)}$

\begin{tabular}{|c|c|c|c|c|c|c|c|c|c|}
\hline \multirow{2}{*}{$\begin{array}{l}\text { Generic } \\
\text { latitude } \\
\text { type }\end{array}$} & \multirow{2}{*}{$\begin{array}{l}\text { Mixed } \\
\text { contrast } \\
\text { category }\end{array}$} & \multirow{2}{*}{$\begin{array}{l}\text { Genotype } \\
\text { (Table } \\
3)^{8)}\end{array}$} & \multicolumn{6}{|c|}{ Cultivation value $\left(C_{\text {val }}\right)$ rating (Peltonen 2010, Eq. 8) } & \multirow{2}{*}{$\begin{array}{l}\text { Mixed } \\
\text { baseline } \\
\text { yield }\left(\mathrm{y}_{\mathrm{b}}\right) \\
{[\mathrm{X}, \pm \mathrm{SD} \text {, }} \\
\left.\mathrm{kg} \mathrm{ha}^{-1}\right]^{7)}\end{array}$} \\
\hline & & & $\begin{array}{l}\mathrm{C}_{\mathrm{val}} \text { sub } \\
\text { class }^{1)}\end{array}$ & $\begin{array}{l}C_{a}{ }^{2)} \\
\text { (d) }\end{array}$ & $\begin{array}{l}\mathrm{C}_{\mathrm{c}}{ }^{3)} \\
\text { Observed } \\
\text { yield } \\
{\left[\mathrm{kg} \mathrm{ha}^{-1}\right]^{7)}}\end{array}$ & $\begin{array}{l}\mathrm{C}_{\mathrm{p}}^{4)} \\
{\left[\mathrm{kg} \mathrm{DMd}^{-1} \mathrm{ha}^{-1} /\right.} \\
\left.\mathrm{N} \mathrm{kg} \mathrm{ha}^{-1}\right]\end{array}$ & $C_{b}{ }^{5)}$ & $\begin{array}{l}\mathrm{C}_{\text {Val }} \\
\text { Tot } \\
\text { Score 6) }\end{array}$ & \\
\hline \multirow{7}{*}{ MidE } & \multirow{5}{*}{$\mathrm{MidE}_{\text {New90 }}$} & Quarna & & $\begin{array}{l}23 \\
104\end{array}$ & $\begin{array}{l}22 \\
4743\end{array}$ & $\begin{array}{l}39 \\
46 / 109\end{array}$ & 39 & $\begin{array}{l}123 \\
\text { Max MidE }\end{array}$ & 4620 \\
\hline & & Amaretto & Elite & $\begin{array}{l}23 \\
107\end{array}$ & $\begin{array}{l}36 \\
5645\end{array}$ & $\begin{array}{l}34 \\
53 / 104\end{array}$ & 28 & 121 & 5474 \\
\hline & & Epos & & $\begin{array}{l}22 \\
109\end{array}$ & $\begin{array}{l}32 \\
5302\end{array}$ & $\begin{array}{l}34 \\
49 / 106\end{array}$ & 33 & 121 & 5224 \\
\hline & & Trappe & Other & $\begin{array}{l}22 \\
110\end{array}$ & $\begin{array}{l}27 \\
5976\end{array}$ & $\begin{array}{l}30 \\
55 / 104\end{array}$ & 24 & 103 & $\begin{array}{l}6241 \\
\text { Max. MidE }\end{array}$ \\
\hline & & $\begin{array}{l}\text { Nandu } \\
\text { Ref. }\end{array}$ & & - & - & - & - & - & 4371 \\
\hline & \multirow{2}{*}{$\mathrm{MidE}_{\mathrm{Old} 80}$} & Matador & & - & - & - & - & - & 4079 \\
\hline & & Pasteur & & - & - & - & - & - & 4387 \\
\hline MidE & MidE $_{\text {old80 }}$ & $\begin{array}{l}\text { Pasteur } \\
\text { Ref. }\end{array}$ & Other & & & & & & $4375 \pm 371$ \\
\hline MidE ${ }^{9)}$ & $\begin{array}{l}\text { MidE }_{\text {New9o }} \\
\pm S D\end{array}$ & $\begin{array}{l}\text { Nandu } \\
\text { Ref. }\end{array}$ & Other & $\begin{array}{l}23 \\
\pm 1.2\end{array}$ & $\begin{array}{l}29 \\
\pm 3.6\end{array}$ & $\begin{array}{l}34.2 \\
\pm 1.8\end{array}$ & $\begin{array}{l}31.2 \\
\pm 3.6\end{array}$ & $\begin{array}{l}117.4 \\
\pm 7.57\end{array}$ & $4755 \pm 282$ \\
\hline MidE & $\begin{array}{l}\text { Generic } \\
\text { Latitude } \\
\text { type }\end{array}$ & $\begin{array}{l}\text { Mid-E. } \\
\text { mean }\end{array}$ & & & & & & & $4922 \pm 554$ \\
\hline \multirow{7}{*}{$\mathrm{HiL}$} & \multirow{7}{*}{$\mathrm{HiL}_{\text {New90 }}$} & Zebra & & $\begin{array}{l}25 \\
106\end{array}$ & $\begin{array}{l}28 \\
5057\end{array}$ & $\begin{array}{l}34 \\
48 / 100\end{array}$ & 32 & 119 & 5053 \\
\hline & & Marble & Elite & $\begin{array}{l}25 \\
107\end{array}$ & $\begin{array}{l}28 \\
5120\end{array}$ & $\begin{array}{l}33 \\
48 / 101\end{array}$ & 31 & 117 & Max HiL \\
\hline & & Wellamo & & $\begin{array}{l}27 \\
106\end{array}$ & $\begin{array}{l}29 \\
5119\end{array}$ & $\begin{array}{l}31 \\
49 / 107\end{array}$ & 32 & 119 MaxHiL & - \\
\hline & & Bjarne & & $\begin{array}{l}23 \\
104\end{array}$ & $\begin{array}{l}19 \\
4556\end{array}$ & $\begin{array}{l}28 \\
44 / 99\end{array}$ & 37 & 107 & - \\
\hline & & Anniina & Quality & $\begin{array}{l}23 \\
101\end{array}$ & $\begin{array}{l}21 \\
4627\end{array}$ & $\begin{array}{l}30 \\
46 / 108\end{array}$ & 36 & 110 & 4387 \\
\hline & & $\begin{array}{l}\text { Kruunu } \\
\text { Ref. }\end{array}$ & & $\begin{array}{l}24 \\
104\end{array}$ & $\begin{array}{l}24 \\
4910\end{array}$ & $\begin{array}{l}33 \\
47 / 97\end{array}$ & 30 & 111 & 4689 \\
\hline & & $\begin{array}{l}\text { Tjalve } \\
\text { Ref. }\end{array}$ & Other & - & - & - & - & - & 4652 \\
\hline $\mathrm{HiL}$ & $\mathrm{HiL}_{\text {old70 }}$ & Apu & Other & - & - & - & - & - & $3886 \pm 341$ \\
\hline $\mathrm{HiL}$ & $\mathrm{HiL}_{\mathrm{old} 80}$ & $\begin{array}{l}\text { Polkka } \\
\text { Ref. }\end{array}$ & Other & - & - & - & - & - & $4014 \pm 297$ \\
\hline $\mathrm{HiL}^{9)}$ & $\begin{array}{l}\text { HiL }_{\text {New9o }} \\
\pm S D\end{array}$ & $\begin{array}{l}\text { Tjalve } \\
\text { Ref. }\end{array}$ & Other & $\begin{array}{l}\mathbf{2 4 . 4} \\
\pm 1.7\end{array}$ & $\begin{array}{l}24.2 \\
\pm 4.3\end{array}$ & $\begin{array}{l}31 \\
\pm 2.1\end{array}$ & $\begin{array}{l}\mathbf{2 3} \\
\pm 2.3\end{array}$ & $\begin{array}{l}\mathbf{1 1 2 . 8} \\
\pm 5.1\end{array}$ & $4616 \pm 564$ \\
\hline $\mathrm{HiL}$ & $\begin{array}{l}\text { Generic } \\
\text { Latitude } \\
\text { type }\end{array}$ & HiL mean & & & & & & & $4532 \pm 573$ \\
\hline
\end{tabular}

${ }^{1} \mathrm{C}_{\mathrm{val}}-$ Cultivation scoring value profile on a genotype level in Zones I-III (Classes: Elite, Quality, Other, Eq. 8, cv. Kruunu Ref.) ${ }^{2)} \mathrm{C}_{\mathrm{a}}{ }^{-}$ adaptation plasticity scoring value with growing days (d) from sowing to full maturity ${ }^{3)} \mathrm{C}_{c}$ - cultivation certainty scoring value with final grain yield $\left(\mathrm{kg} \mathrm{ha}^{-1}\right)^{4)} \mathrm{C}_{\mathrm{p}}$ - cultivation properties scoring value containing grain yield accumulation/growing day ratio (kg DM/d) and the nitrogen amount in grains $\left(\mathrm{N} \mathrm{kg} \mathrm{ha}^{-1}\right)^{5)} \mathrm{C}_{\mathrm{b}}$ - baking quality scoring value ${ }^{6)} \mathrm{C}_{\mathrm{v}}$ - Cultivation total scoring value of a genotype (Eq. 8) in growing zones I-III. 7) Observed mean yields from dataset VII (Fig. 1), ${ }^{8)}$ Ref. - Reference genotype. ${ }^{9}$ Generic reference genotype in the Mixed New ${ }_{90}$ contrast category. 
The $C_{\text {valtot }}$ scoring value consisted of cultivation properties $\left(C_{p}\right)$, adaptation plasticity $\left(C_{a}\right)$, baking quality $\left(C_{b}\right)$ and cultivation certainty $\left(C_{c}\right)$ subcomponents (Peltonen 2010). Especially cv. 'Quarna' (Elite and MidE ${ }_{\text {New90 }}$ classes) obtained the highest Cultivation total scoring value $\left(C_{\text {valTot }} 123\right)$, the $C_{a^{\prime}} C_{c}$ and $C_{p}$ components were 23,2239 . The Mixed mean baseline yield estimate was $\left(\mathrm{y}_{\mathrm{b}}\right) 4620 \mathrm{~kg} \mathrm{ha}^{-1} \mathrm{vs} .4743 \mathrm{~kg} \mathrm{ha}^{-1}$ observed mean yield level.

With cv. 'Quarna' the grain yield accumulation/growing day ratio was $46 \mathrm{~kg} \mathrm{DM} \mathrm{d}^{-1} \mathrm{ha}^{-1}$ and the nitrogen amount in grains was $109 \mathrm{~N} \mathrm{~kg} \mathrm{ha}^{-1}$ and the mean growing days from sowing to full maturity were $104 \mathrm{~d}$. The cv. 'Wellamo' obtained 119 and cv. 'Marble' 117 in total scoring $\left(\mathrm{C}_{\text {valTot }}\right)$, both cv. 'Wellamo' and 'Marble' yielded above $5 \mathrm{t}$ $\mathrm{ha}^{-1}$ average yield levels. The reference genotype 'Kruunu' (HiL ${ }_{\mathrm{New90}}$ ' Quality class) obtained 111 in total scoring.

Especially HiL and MidE generic reference genotypes in the Mixed New ${ }_{90}$ contrast category (MidE ${ }_{\text {New90 }}$ and $\mathrm{HiL}_{\text {New90, }}$ Table 5) were utilized when defining the ideotype profiles (Itprf ${ }_{\text {Mide,HiL }}$ Eq. 10) in conjunction with the CERES-Wheat crop model. The HiL $\mathrm{New}_{\text {No }}$ generic genotype factors $\left(\mathrm{y}_{\mathrm{b}}, \mathrm{kg}\right.$ ha-1 $\left.\left.\pm S D\right], \mathrm{C}_{\mathrm{p}}, \mathrm{C}_{\mathrm{a}}, \mathrm{C}_{\mathrm{b}}, \mathrm{C}_{\mathrm{c}^{\prime}}, \mathrm{C}_{\mathrm{valTot}}\right)$ were $(4616 \pm 564,24.4 \pm 1.7,24.2 \pm 4.3,31.0 \pm 2.1,23.0 \pm 2.3,112.8 \pm 5.1)$ and the corresponding factors for the MidE ${ }_{\text {New } 90}$ generic genotype were $(4755 \pm 282,23.0 \pm 1.2,29.0 \pm 3.6,34.2 \pm 1.8,31.2 \pm 3.6,117.4 \pm 7.57)$.

\section{Path coefficient analysis results with yield $\left(\mathrm{p}_{\mathrm{y}}\right)$ and vegetation $\left(\mathrm{p}_{\mathrm{v}}\right)$ components}

Table 6 presents Path coefficient modeling results (Models I-IV) for HiL ideotypes using datasets VIII and IX (Fig 1., Phase III) with estimates for correlation coefficients $(r)$, values for coefficient of determination $\left(R^{2}\right)$ and $U$ residual factors (Eq. 2-7). With Path models I-III and using vegetation components $\left(p_{v}\right)$ as independent variables, $R^{2}$ values were relatively low (I:0.219, II:0.08, III: 0.351).

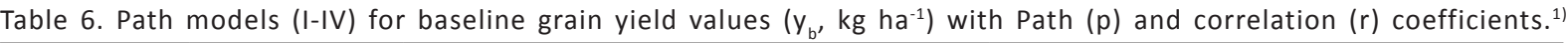

\begin{tabular}{|c|c|c|c|c|c|c|}
\hline $\begin{array}{l}\text { Path - } \\
\text { Model }\end{array}$ & $\begin{array}{l}\mathrm{y}_{\mathrm{b}} \text { for a generic } \\
\text { HiL ideotype } \\
\mathrm{X},(\mathrm{SD}) \\
\left(\mathrm{kg} \mathrm{ha}^{-1}\right)\end{array}$ & $\begin{array}{l}\text { Linear regression for } \\
\text { baseline } \\
\mathrm{y}_{\mathrm{b}}\left(\mathrm{kg} \mathrm{ha} \mathrm{a}^{-1}\right) \\
=\mathrm{b}_{0}+\mathrm{b}_{1}^{*} \times 1+\mathrm{b}_{2}^{*} \times 2+. . \\
\mathrm{b}_{\mathrm{n}}^{*} \times(\text { Eq. } 2)\end{array}$ & $\begin{array}{l}\text { Standardized Path } \\
\text { Model for baseline } \\
\text { grain yield ( } p=\text { Path- } \\
\text { and } r=\text { correlation } \\
\text { coefficients } \\
\text { (Eq. 5) } \\
y_{b}=p a * r a * A+p b * \\
r b * B . . p c * r c x\end{array}$ & $\begin{array}{l}\mathrm{R}^{2} \text { for grain yield } \\
\mathrm{kg} \mathrm{ha}^{-1} 15 \% \text { moist. } \\
\text { cont.) } \\
\text { (Eq. 7) }{ }^{2)}\end{array}$ & $\begin{array}{l}p_{v}{ }^{2)} \\
p_{y}{ }^{3)}\end{array}$ & $\begin{array}{l}\mathrm{R}^{2} \\
(\mathrm{U})^{4)}\end{array}$ \\
\hline $\begin{array}{l}\text { I } \\
(p v)^{5)}\end{array}$ & 3105.0 (342.3) & $\begin{array}{l}3443.71-0.32 *\left(\mathrm{Fla}_{\text {June }}\right) \\
+0.29 *\left(\mathrm{Fla}_{\text {July }}\right) \\
-0.37 *\left(\mathrm{FIDW}_{\text {June }}\right) \\
+10.44 *\left(\mathrm{FIDw}_{\text {July }}\right)\end{array}$ & 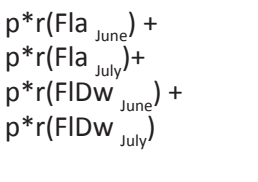 & $\begin{array}{l}(-0.14 * 0.046)+ \\
(0.25 * 0.38)+ \\
(-0.102 *-0.003)+ \\
(+0.31 * 0.414)= \\
0.2190\end{array}$ & $\begin{array}{l}-0.140^{2)} \\
+0.250 \\
-0.102 \\
+0.310\end{array}$ & $\begin{array}{l}0.2190 \\
(0.682)\end{array}$ \\
\hline $\begin{array}{l}\text { II } \\
(p v)^{5)}\end{array}$ & 3860.7 (192.0) & $\begin{array}{l}3522.9+0.38 *\left(2 \operatorname{LfA}_{\text {June }}\right) \\
+0.14 *\left(2 \mathrm{LfA}_{\text {June }}\right)- \\
0.14 *\left(2 \mathrm{LfDW}_{\text {June }}\right) \\
-0.27\left(2 \mathrm{Lf} \mathrm{DW}_{\text {July }}\right)\end{array}$ & $\begin{array}{l}p^{*} r\left(2 \text { LfA }_{\text {June }}\right)+ \\
p^{*} r\left(2 \text { LfA }_{\text {June }}\right)+ \\
p^{*} r\left(2 \text { LfDw }_{\text {June }}\right)+ \\
p^{*} r\left(2 \text { Lf Dw }_{\text {July }}\right)\end{array}$ & $\begin{array}{l}(0.397 * 0.209)+ \\
(0.15 * 0.034)+ \\
(-0.142 * 0.038) \\
+(-0.296 *-0.055)= \\
0.085\end{array}$ & $\begin{array}{l}+0.397^{2)} \\
+0.150 \\
-0.142 \\
-0.296\end{array}$ & $\begin{array}{l}0.085 \\
(0.891)\end{array}$ \\
\hline $\begin{array}{l}\text { III } \\
(p v)^{5)}\end{array}$ & 3158.7 (304.4) & $\begin{array}{l}2820.5-0.11\left(\text { FIDW }_{\text {June }}\right) \\
-0.068 *\left(2 \text { LfDW }_{\text {June }}\right) \\
-0.49 *\left(\text { FIDW }_{\text {July }}\right) \\
+0.68 *\left(2 \text { LfDW }_{\text {July }}\right)\end{array}$ & $\begin{array}{l}P^{*} r\left(F_{D W} W_{\text {June }}\right)+ \\
P^{*} r\left(2 L_{f D W_{\text {June }}}\right)+ \\
P^{*} r\left(F_{D W} W_{\text {July }}\right)+ \\
P * r\left(2 L_{\text {July }}\right)\end{array}$ & $\begin{array}{l}(-0.124 *-0.003)+ \\
(-0.077 * 0.038)- \\
(-0.538 * 0.414)+ \\
(0.788 *-0.055)= \\
0.351\end{array}$ & $\begin{array}{l}-0.124^{2)} \\
-0.077^{2} \\
-0.538 \\
+0.788\end{array}$ & $\begin{array}{l}0.351 \\
(0.951)\end{array}$ \\
\hline $\begin{array}{l}\text { IV } \\
(p y)^{6)}\end{array}$ & $\begin{array}{l}3461.0 \\
(90.6)\end{array}$ & 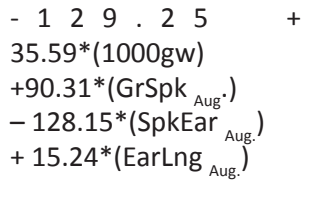 & $\begin{array}{l}p^{*} r(1000 \text { gw })+ \\
p^{*} r\left(\text { GrEar }_{\text {Aug. }}\right)+ \\
p^{*} r\left(\text { SpkEar }_{\text {Aug. }}\right)+ \\
p^{*} r\left(\text { Earlng }_{\text {Aug. }}\right)+ \\
p^{*} r\left(\text { EarStem }_{\text {Aug. }}\right)\end{array}$ & $\begin{array}{l}(0.679 * 0.39)+ \\
(0.581 * 0.42)+ \\
(-0.306 *-0.33)+ \\
(0.281 * 0.38)+ \\
(0.562 *-0.048)= \\
0.7098\end{array}$ & $\begin{array}{l}+0.679^{3)} \\
+0.581 \\
-0.306 \\
+0.281 \\
+0.562\end{array}$ & $\begin{array}{l}0.7098 \\
(0.797)\end{array}$ \\
\hline
\end{tabular}


Correspondingly with Path model IV and using yield components $\left(p_{y}\right)$ as independent variables, $R^{2}$ was high (0.709). The Path-model dependent variable, baseline grain yield $\left(\mathrm{y}_{\mathrm{b}}\right)$ estimate was for a generic HiL ideotype with Model I: $3105.0 \mathrm{~kg} \mathrm{ha}^{-1}$ (SD $342.3 \mathrm{~kg} \mathrm{ha}^{-1}$ ), Model II: 3860.7 (192.0), Model III: 3158.7 (304.4) and Model IV: 3461.0 (90.6). The overall mean HiL grain yield estimate $\left(y_{b}\right)$ was $3396 \mathrm{~kg} \mathrm{ha}^{-1}$ (SD $232 \mathrm{~kg} \mathrm{ha}^{-1}$ ).

\section{Vegetation Path-coefficient $\left(\mathrm{p}_{\mathrm{v}}\right)$ estimations and leaf area and dry weight variation}

The vegetation Path coefficients $\left(p_{v}\right)$ results for HiL genotypes (models I-III, Table 7, Fig 1., Phase III) indicate, that significant vegetation components $\left(\mathrm{p}_{\mathrm{v}}\right)$ on final grain yield $\left(\mathrm{y}_{\mathrm{b}}\right)$ and 1000 kernel weight were number of leaves/ plant in June $\left(0.477\right.$, SD 0.18), both flag leaf area $\left(0.386\right.$, SD 0.17, $\mathrm{L}_{7}$ leaf development phase, Peltonen-Sainio et al., 2005) and flag leaf dry weight in July $(0.611$, SD 0.24) and dry weights of whole plants in June $(0.505$, SD 0.24). The number of side tillers in June, the length of main stem in June, July and August and the second highest leaf area in July had significant direct effects on final 1000 kernel weight.

Table 7. HiL vegetation Path-coefficients $\left(\mathrm{p}_{\mathrm{v}}\right)$ and PCA factor loadings vs. baseline grain yield $\left(\mathrm{y}_{\mathrm{b}^{\prime}} \mathrm{kg}\right.$ ha-1) and vs. 1000 grain weight (g).

\begin{tabular}{|c|c|c|c|}
\hline Vegetation parameter & $\begin{array}{l}p_{v} v s . \text { baseline } \\
\text { grain yield } \\
\left(\mathrm{y}_{\mathrm{b}}, \mathrm{kg} \mathrm{ha}^{-1}\right) \\
(\mathrm{SD})^{1)}\end{array}$ & $\begin{array}{l}p_{v} \text { vs. } \\
1000 \text { grain weight }(g) \\
(S D)^{1)}\end{array}$ & $\begin{array}{l}\text { PCA factor loadings } \\
\text { ( } 2 \text { factor solution) }\end{array}$ \\
\hline Side tillers in June & $0.200(0.187)$ & $0.584(0.113)$ & +0.558 \\
\hline Number of leaves in June & $0.477(0.183)$ & $0.131(0.110)$ & +0.377 \\
\hline The length of main stem in June, July, August & $0.070,0.360,0.570$ & $0.640,0.703,0.316$ & $\begin{array}{l}+0.873,+0.804 \\
+0.783\end{array}$ \\
\hline Flag leaf area $\left(\mathrm{mm}^{2}, \mathrm{~L}_{7}\right)$ phase in June and July ${ }^{2)}$ & $\begin{array}{l}0.153(0.050) \\
0.386(0.176)\end{array}$ & $\begin{array}{l}0.012(0.080) \\
0.131(0.233)\end{array}$ & $+0.324,+0.661$ \\
\hline Second leaf area $\left(\mathrm{mm}^{2}\right)$ in June and July & $\begin{array}{l}0.226(0.166) \\
0.042(0.073)\end{array}$ & $\begin{array}{l}0.088(0.061) \\
0.541(0.110)\end{array}$ & $+0.681,-$ \\
\hline Flag leaf dry weight (mg) in June and July & $\begin{array}{l}0.139(0.063) \\
0.611(0.243)\end{array}$ & $\begin{array}{l}0.393(0.103) \\
0.141(0.175)\end{array}$ & $+0.345,+0.369$ \\
\hline Second leaf dry weight $(\mathrm{mg})$ in June and July & $\begin{array}{l}0.216(0.080) \\
0.237(0.170)\end{array}$ & $\begin{array}{l}0.108(0.121) \\
0.259(0.175)\end{array}$ & +0.703 \\
\hline Dry weight of rest of plant ( $\mathrm{mg}$ ) in June and July & $\begin{array}{l}0.512(0.050) \\
0.205(0.134)\end{array}$ & $\begin{array}{l}0.251(0.207) \\
0.085(0.327)\end{array}$ & $+0.784,-$ \\
\hline $\begin{array}{l}\text { Dry weight of whole plant (excluding root bm.) } \\
\text { in June and July }\end{array}$ & $\begin{array}{l}0.505(0.244) \\
0.231(0.525)\end{array}$ & $\begin{array}{l}0.339(0.281) \\
0.339(0.477)\end{array}$ & $+0.827,-$ \\
\hline Dry weight of straw biomass (mg) in August & $0.062(0.052)$ & $0.341(0.071)$ & +0.504 \\
\hline
\end{tabular}

1) Standard deviation (SD) denotes variance with different Path-model combinations from models I-III (Table 6)

${ }^{2)} L_{7}$ leaf development phase (Peltonen-Sainio et al., 2005)

\section{Yield component Path-coefficient $\left(\mathrm{p}_{\mathrm{y}}\right)$ estimations}

In table 8, the Path-model IV (Fig 1., Phase III) indicated a strong direct connection with HiL yield component Pathcoefficients $\left(p_{y}\right)$ between final baseline grain yield $\left(y_{b}\right)$ and 1000 grain weight $(0.679)$ and Harvest Index $(H I, 0.480)$. In addition, model IV had a high overall coefficient of determination ( $R^{2} 0.709$, Table 6). Grains/head (0.581), head bearing stalks $(0.562)$ and head length $(0.281)$ had also strong positive effect on final grain yield determination in grain filling phase after anthesis. 
Table 8. HiL yield component Path-coefficients $\left(\mathrm{p}_{\mathrm{y}}\right)$ and PCA factor loadings vs. baseline grain yield $\left(\mathrm{y}_{\mathrm{b}}\right)$ and vs. 1000 grain weight $(\mathrm{g})$

\begin{tabular}{llll}
\hline Yield component & $\begin{array}{l}\mathrm{P}_{\mathrm{y}} \text { vs. baseline grain yield } \\
\left(\mathrm{y}_{\mathrm{b}}, \mathrm{kg} \mathrm{ha}^{-1}\right)\end{array}$ & $\mathrm{P}_{\mathrm{y}}$ vs. 1000 grain weight $(\mathrm{g})$ & $\begin{array}{l}\text { PCA factor loadings } \\
(2 \text { factor solution })\end{array}$ \\
\hline 1000 grain weight $(\mathrm{g})$ & 0.679 & - & +0.554 \\
Harvest Index $(\mathrm{HI})$ & 0.480 & 0.338 & - \\
Grains/head & 0.581 & 0.791 & +0.347 \\
Head bearing stalks $\mathrm{m}^{-2}$ & 0.562 & 0.644 & +0.618 \\
Main head length $(\mathrm{mm})$ & 0.281 & 0.061 & +0.383 \\
Spikelets/head & -0.306 & 0.219 & - \\
\hline
\end{tabular}

The high $\mathrm{p}_{\mathrm{y}}$ yield component factor (0.581) between grains/head and final grain yield confirms the positive direct effect. This was also noted with vegetative parameters, especially with flag leaf area and dry weights with high $\mathrm{p}_{\mathrm{v}}$ values in generative phase in July.

The Principal Component Analysis (PCA) analysis results (phase IIla, Fig.1) with high positive PCA factor loadings for vegetation (Table 7) and yield components (Table 8 ) indicated, that especially head bearing stalks $\mathrm{m}^{-2}$, the length of main stem and the plant above ground dry weight were significant factors affecting both final grain yield and 1000 grain weight determination with HiL genotypes.

\section{Ideotype profiles (ItPrf) for generic HiL and MidE spring wheat genotypes}

Table 9 illustrates the CERES-Wheat phenological (PHINT, P1V, P1D and P5) and yield component coefficient (G1, G2 and G3) calibration results for HiL and MidE generic genotypes using the RMSD algorithm (Root Mean Square Difference, Eq. 9, Laurila 2001). The average anthesis difference (RMSD ${ }_{\text {ANTH }}$ ) was $2.99 \mathrm{~d}$ assuming that the anthesis is reached on average ca. 5 days after wheat heading, the full maturity difference (RMSD ${ }_{F M A T}$ ) was $5.86 \mathrm{~d}$ and the baseline yield levels $\left(\mathrm{y}_{\mathrm{b}}\right)$ difference was $1.79 \mathrm{t} \mathrm{ha}^{-1}\left(\mathrm{RMSD}_{\mathrm{YLD}}\right)$ pooled over all soil types derived from the MTT Agrifood Research Official Variety Trial dataset (1978-2007, Dataset I, Table 1, Kangas et al. 2006, 2008).

The calibrated genetic coefficients (PHINT, P1V, P5, G1, G2, G3) were for a generic HiL genotype (60.0, 0.10, 1.0, 10.0, 5.0, 1.0, 1.5) and respectively for a generic MidE genotype (60.0, 0.10, 1.0, 9.0, 4.0, 3.0, 2.0).

Table 9. The CERES-Wheat (Jones et al. 2003) calibrated yield component coefficients (G1, G2 and G3) and phenological coefficients (PHINT, P1V, P1D and P5) for HiL (cv. Polkka ref., Laurila, 2001) and for MidE (cv. Nandu ref., Laurila, 1995) genotypes.

\begin{tabular}{|c|c|c|c|c|c|c|}
\hline Generic genotype & Soil type & $\begin{array}{l}\text { RMSD } D_{Y L D} \\
\left(\mathrm{t} \mathrm{ha}^{-1}\right)^{1)}\end{array}$ & G1 & G2 & G3 & \\
\hline $\begin{array}{l}\text { MidE } \\
\text { (cv. Nandu ref.) }\end{array}$ & All soil data pooled & - & 4.0 & 3.0 & 2.0 & \\
\hline \multirow{6}{*}{$\begin{array}{l}\text { HiL } \\
\text { (cv. Polkka ref.) }\end{array}$} & Sand (coarse and fine) & 1.7478 & 0.50 & 5.00 & 5.00 & \\
\hline & Heavy clay & 1.8323 & 1.00 & 8.50 & 1.00 & \\
\hline & Mixed clays & 1.7245 & 1.00 & 8.50 & 1.00 & \\
\hline & Silt, Silt loam & 1.4080 & 1.00 & 6.00 & 1.00 & \\
\hline & $\begin{array}{l}\text { Organic soil (Peat, } \\
\text { Mould) }\end{array}$ & 0.2892 & 2.00 & 2.30 & 2.00 & \\
\hline & All soil data pooled & 1.7980 & 5.00 & 1.00 & 1.50 & \\
\hline $\begin{array}{l}\text { Generic genotype \& } \\
\text { Phenology }\end{array}$ & $\begin{array}{l}\mathrm{RMSD}_{\text {ANTH }} \\
\text { (d) }\end{array}$ & $\begin{array}{l}\mathrm{RMSD}_{\text {FMAT }} \\
\text { (d) }\end{array}$ & $\begin{array}{l}\text { PHINT } \\
\text { (dd) }\end{array}$ & P1V & P1D & P5 \\
\hline HiL (cv. Polkka ref.) & 2.99 & 5.86 & 60.0 & 0.10 & 1.00 & 10.0 \\
\hline MidE (cv. Nandu ref.) & - & - & 60.0 & 0.10 & 1.00 & 9.0 \\
\hline
\end{tabular}

${ }^{1} \mathrm{RMSDYLD}=\mathrm{RMSD}$ for grain yield $\left(\mathrm{t} \mathrm{ha}^{-1}\right) .{ }^{2)} \mathrm{RMSD}_{\mathrm{ANTH}}=\mathrm{RMSD}$ for anthesis $(\mathrm{d})$, the anthesis is reached ca. 5 days after heading,

${ }^{3)} \mathrm{RMSD}_{\mathrm{FMAT}}=\mathrm{RMSD}$ for full maturity $(\mathrm{d})$. 
The combined statistical Mixed Covariance, Cultivation value (Table 5) results and modeling results from the dynamic CERES-Wheat crop model on wheat non-potential baseline yield ( $\mathrm{y}_{\mathrm{b}} \mathrm{kg} \mathrm{ha}^{-1}$, Table 9) were synthesized as generic ItPrf ${ }_{\text {HiL,New90 }}$ and ItPrf ${ }_{\text {MidE,New90 }}$ ideotype profiles in the New90 Mixed contrast category including genotypes introduced into cultivation in the 1990s or later (Fig 1., Phase IV).

The statistical modeling results yielding generic HiL and MidE genotypes (Table 5) and results from the CERESWheat crop model with phenological and yield component factors (Table 9) were combined as ItPrf HiL,New90 $_{\text {and }}$ ItPrf $_{\text {MidE,New9o }}$ ideotype profiles (Eq. 10). The elevated atmospheric $\mathrm{CO}_{2}$ concentration (700 ppm) combined with $+3^{\circ} \mathrm{C}$ mean diurnal temperature change factors on wheat non-potential baseline yield $\left(\mathrm{y}_{\mathrm{b}} \mathrm{kg} \mathrm{ha}^{-1}\right)$ were included in ItPrf HiL,New90 and ItPrf ${ }_{\text {Mide,New90 }}$ ideotype profiles simulating the year 2100 climate change scenario in southern Finland (Carter 2004).

$\operatorname{ItPrf}(\mathrm{HiL} / \mathrm{MidE}(\mathrm{New} 90))=(\mathrm{yb} \pm \mathrm{SD}, \Delta \mathrm{yb}(\mathrm{CO} 2,700 \mathrm{ppm})[\mathrm{min} .-\max ., \%]$, $\Delta \mathrm{yb}\left(\Delta \mathrm{T},+3^{\circ} \mathrm{C}\right)[\min .-\max ., \%], \Delta \mathrm{yb}(\mathrm{CO} 2, \mathrm{TempCov})[\min .-\max ., \%]$, PHINT, P1V, P5, G1, G2, G3, Ca , Cp , Cb , CValTot)

where (i) $y_{b} \pm S D$ is the mean non-potential baseline grain yield level $\left(\mathrm{kg} \mathrm{ha}^{-1}\right)$ without the $\mathrm{y}_{b(\mathrm{CO} \text {, Tempcov) }}$ covariance effect (ii) the $\mathrm{y}_{\mathrm{b}(\mathrm{CO}, 700 \mathrm{ppm})}$ factor estimates the change range (min.-max., \%) on baseline yield $\left(\mathrm{y}_{\mathrm{b}} \mathrm{kg} \mathrm{ha}^{-1}\right)$ with doubled atmospheric $\mathrm{CO}_{2}$ concentration $(700 \mathrm{ppm})$, (iii) the $\mathrm{y}_{\mathrm{b}(\Delta \mathrm{T},+3 \circ \mathrm{c})}$ factor estimates the change range (min.-max., $\left.\%\right)$ on $\mathrm{y}_{\mathrm{b}}$ with $+3 \stackrel{\circ}{\circ}$ mean diurnal temperature change $(\Delta T)$ and (iv) the covariance factor $\mathrm{y}_{\mathrm{b}(\mathrm{CO} \text {, Tempcov) }}$ estimates the change range (min.-max.,\%) on $\mathrm{y}_{\mathrm{b}}$ with concurrent doubled $\mathrm{CO}_{2}$ concentration and with +3 을 $\mathrm{C}$ mean diurnal temperature

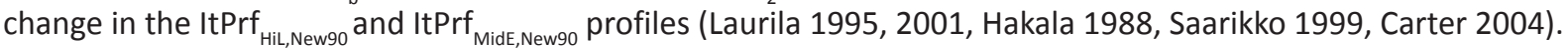

The $\Delta \mathrm{y}_{\mathrm{b}(\mathrm{CO} 2,700 \mathrm{ppm}),} \Delta \mathrm{y}_{\mathrm{b}(} \Delta \mathrm{T}_{,+30 \mathrm{C})}$ and the covariant $\Delta \mathrm{y}_{\mathrm{b}(\mathrm{CO} 2, \mathrm{TempCov})}$ factors in the ideotype profiles were excluded from the non-potential baseline yield estimates $\left(\mathrm{y}_{\mathrm{b}}\right.$, Eq. 10). The covariant $\Delta \mathrm{y}_{\mathrm{b}(\mathrm{CO} \text {, Tempcov })}$ factor simulating the concurrent elevated $\mathrm{CO}_{2}$ and temperature effects in conjunction with the HiL and MidE non-potential baseline yield es-

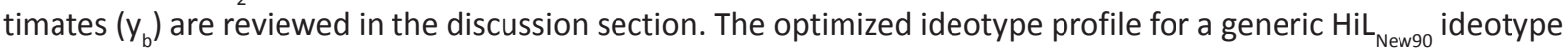
$\left(\right.$ ItPrf $\left._{\text {HiL, New90 }}\right)$ with parameters $\left(\mathrm{y}_{\mathrm{b}} \pm \mathrm{SD}\left[\mathrm{kg} \mathrm{ha}^{-1}\right], \Delta \mathrm{y}_{\mathrm{b}(\mathrm{CO} 2,700 \mathrm{ppm})}[\min .-\max ., \%], \Delta \mathrm{y}_{\mathrm{b}\left(\Delta \mathrm{T},+3^{\circ} \mathrm{C}\right)}[\min .-\mathrm{max} . \%], \Delta \mathrm{y}_{\mathrm{b}(\mathrm{CO} 2, \mathrm{TempCov})}\right.$ [min.max., \%], PHINT [dd], P1V, P5, G1, G2, G3, $C_{a}, C_{p}, C_{b}, C_{\text {ValTot }}$, Eq. 10) was (4616 $1564,1.12-1.42,0.72-0.83,1.01-1.06$, $60.0,0.10,1.0,10.0,5.0,1.0,1.5,24.4,24.2,31,23,112.8)$. The optimized ideotype profile (ItPrf ${ }_{\text {Mide, New90 }}$ ) for a generic MidE $_{\text {New90 }}$ ideotype was $(4755 \pm 282,1.49-1.72,0.59-0.62,1.04-1.13,60.0,0.10,1.0,9.0,4.0,3.0,2.0$, $23,29,34.2,31.2,117.4)$.

\section{Discussion}

\section{Spring wheat yield trends in Finland}

According to Mela and Suvanto (1987), $\mathrm{HiL}_{\mathrm{Old70}}$ and $\mathrm{HiL}_{\mathrm{Old80}}$ spring wheat genotypes increased the average baseline yield $\left(\mathrm{y}_{\mathrm{b}}\right)$ levels by $+0.34 \%$ /year in Finland during the period 1956-1985 due to improved plant breeding and other cultivation techniques. A general trend of breaking the averaged $5 \mathrm{t} \mathrm{ha}^{-1}$ baseline barrier $\left(\mathrm{y}_{\mathrm{b}}\right)$ over the years with MidE $_{\text {New90 }}$ genotypes introduced into cultivation after the 1990s is noticeable in the MTT Agrifood Research Finland 1978-2007 official variety trial data (Dataset I). Recently Peltonen-Sainio et al. (2009) concluded using the Finnish MTT official variety trial (1970-2005) data and FAOSTAT data (1960-2005) that the yield trends of future wheat genotypes will constantly increase in Finland and on global scale during climate change because of the increasing demand for global food production. In practical cultivation in southern Finland, the average yield levels have been rising steadily from the old $3 \mathrm{t} \mathrm{ha}^{-1}$ average level above $5 \mathrm{t} \mathrm{ha} \mathrm{H}^{-1}$ in southern Finland by using new $\mathrm{HiL}_{\mathrm{New} 90}$ and $\mathrm{MidE}_{\text {New90 }}$ genotypes, incorporated with new fertilizer and pesticide practices (Kangas et al. 2008, Peltonen 2010). The increase of sowing seed density from 600 seeds $\mathrm{m}^{-2}$ to 700 seeds $\mathrm{m}^{-2}$ has increased the yield levels by $1 \mathrm{t} \mathrm{ha}^{-1}$. Peltonen (2010) reported promising high yield results in southern Finland using new spring wheat cultivars from the $\mathrm{MidE}_{\mathrm{New90}}$ category (e.g. cv. 'Quarna', 'Amaretto', 'Trappe', 'Piccolo', 'Triso', 'Jondolar') and from the HiL $_{\text {New90 }}$ category from Borealis (cv. 'Marble', 'Wellamo') and cv. 'Zebra' from Svalöf-Weibull. 


\section{Optimum vegetation and yield components for high yielding wheat ideotypes}

Path coefficient analysis using datasets VIII and IX identified several significant vegetation $\left(p_{\mathrm{v}}\right)$ and yield components $\left(p_{y}\right)$ with direct effects for HiL wheat ideotypes with maximum yield capacity. The overall mean $y_{b}$ estimate (Models I-IV) for a generic HiL ideotype was $3589 \mathrm{~kg} \mathrm{ha}^{-1}$ (SD $338.7 \mathrm{~kg} \mathrm{ha}^{-1}$ ). Following HiL vegetation $\left(\mathrm{p}_{\mathrm{v}}\right)$ components with corresponding threshold values for high yield capacity were significant: sowing seed density $(>700$ seeds $\left.\mathrm{m}^{-2}\right)$, emerged seedlings $\mathrm{m}^{-2}\left(>600\right.$ seeds $\left.\mathrm{m}^{-2}\right)$, maximum side tillers/plant in June $(>2)$, maximum number of leaves/plant in July (>5), maximum flag leaf and second highest leaf areas $\left(>1800 \mathrm{~mm}^{2}\right.$ and $\left.>1600 \mathrm{~mm}^{2}\right)$ in July, maximum flag leaf and second highest leaf dry weights ( $>57 \mathrm{mg}$ and $>46 \mathrm{mg}$ ) and maximum plant whole dry weight (> $1390 \mathrm{mg}$ ) in August.

The highest yielding $\mathrm{cv}$. 'Kadett' in the HiL $\mathrm{Old80}_{\text {c }}$ category had the highest flag leaf dry weight in June in datasets VIII and IX. This indicated an effective photosynthetic mechanism and high assimilation capacity in vegetative phase in June. In July, in generative phase, the dry weights of flag and the second highest leaves had decreased from June values as the senescence of leaves already had started.

With HiL yield components $\left(p_{y}\right)$ especially grains/ear (> 30), 1000 kernel weight (> 40 g), harvest index (HI>39), spikelets/ear (>12) and ear bearing stems $\mathrm{m}^{-2}$ (> 647) were significant. Peltonen-Sainio et al. (2005) reported that in Finnish growing conditions grains/ear component is one of the most important factors defining the ideotype final grain yield. The current cereal genotypes contain ca. 25 grains per ear on average. In our field results (Datasets VIII-IX), the average grains/ear was higher (42.3, SD 5.3) suggesting above average baseline yield levels for HiL genotypes. Theoretically, there are ca. 160 grain primordiums in the wheat ear (Slafer and Savin 1994). According to Peltonen-Sainio et al. (2005) there is a critical cereal flowering period ("window of opportunity for yield") in Finnish long-day growing conditions, which defines the critical yield component grains/ear number. This period starts on average three weeks before heading, and lasts ca. two weeks ( $<50$ on Zadoks growth scale, Zadoks et al. 1984) with wheat flower differentiation setting the final grain number in head (Sinclair and Jamieson 2008). In our study the average 1000 kernel weight was below average 32.8 (SD 2.6) when compared with the average 37 $\mathrm{g}$ in MTT spring wheat variety trials (Dataset I, Kangas et al. 2006, 2008). Respectively the ear bearing stems $\mathrm{m}^{-2}$ was above average 647.7 (SD 63.2) vs. 500 stems $\mathrm{m}^{-2}$ in MTT trials.

\section{Genotypexenvironmental (G×E) variation and covariances}

The Mixed model soil type contrast results expressing the genotypexenvironmental (GXE) covariance indicated, that clay type soils produced higher baseline yields $\left(y_{b} 4100 \mathrm{~kg} \mathrm{ha}^{-1}\right)$ than coarse $\left(\mathrm{y}_{\mathrm{b}} 3850 \mathrm{~kg} \mathrm{ha}^{-1}\right)$ and loam soil types $\left(y_{b} 3700 \mathrm{~kg} \mathrm{ha}^{-1}\right)$ when using the same cultivars. This was due to the frequent drought periods during growing season on coarse and loam type soils reducing the cereal yield potential (Järvi et al. 1997, Kangas et al. 2008). Recently, Rajala et al. (2009) studied in Finland the effects of water limitation and fertilizer availability on development of yield components. The greenhouse experiment results, using cv. 'Amaretto' (MidE ${ }_{\text {Newgo }}$ ) with different water treatments, indicated that especially plants per unit land area, spikes per plant, grains per spikelet, and single grain weight (SGW) were significant components affecting final grain yield when water and nitrogen availability were limiting factors.

The Mixed modeling results using conventional vs. organic cultivation practices with the same cultivars in the experiments suggested, that genotypes using conventional cultivation practices $\left(y_{b} 4270 \mathrm{~kg} \mathrm{ha}^{-1}\right)$, with herbicide introduction and chemical fertilizers, had ca. $600 \mathrm{~kg} \mathrm{ha}^{-1}$ higher yield capacity compared with genotypes using organic cultivation practices $\left(y_{b} 3640 \mathrm{~kg} \mathrm{ha}^{-1}\right)$. According to Aula and Talvitie (1995) growing period from sowing to full maturity is ca. 1-2 days longer in organic cultivation in Finland compared with conventional cultivation practices.

\section{Source-sink variation and adaptation between ideotypes}

Inter- and intracultivar source-sink variation with high yielding wheat genotypes has been reviewed by Slafer \& Savin (1994) and by Reynolds et al. (2007). Previous studies have indicated a significant morphological variation in leaf angle, leaf weight and leaf area duration between wheat genotypes (Austin et al. 1980). Ledent (1979) and Gent \& Kiyomoto (1985) reported the crucial roles of wheat flag leaf $\left(L_{7}\right)$ and the second highest leaf on yield formation. Peltonen-Sainio et al. (2005) and Peltonen-Sainio \& Rajala (2007) studied detailed cereal leaf development order $\left(L_{1}-L_{7}\right)$ starting from the emergence of cotyledon leaf $\left(L_{1}\right)$ from coleoptile following consecutive phases until the flag leaf $\left(L_{7}\right.$, highest leaf) emerged below the head. In Finnish long day growing conditions cereals differentiate six or seven leaves in the main stem. 
The Mixed structural covariance and Path coefficient results detected several direct and indirect factors affecting the final grain yield with HiL and MidE genotypes. Results indicated a strong intracultivar source-sink correlation between source (e.g. flag leaf area during $\mathrm{L}_{7}$ leaf and $\mathrm{LAI}_{\max }$ development phases) and sink components (e.g. grains/ear, final grain kernel size in the head and harvest index) in the $\mathrm{HiL}_{\text {old70, }} \mathrm{HiL}_{\text {old80 }}$ and $\mathrm{HiL}_{\text {new90 }}$ contrast categories. These modeling results are consistent with the PCA and Path coefficient analysis results published by Reynolds et al. (2007) reviewing source-sink traits and interactions with yield, biomass and radiation use efficiency (RUE) for wheat genotypes with high yield capacity. Reynolds et al. (2007) stated that source-sink imbalance and sink strength are still critical yield limiting factors in wheat genotypes.

When analyzing the Mixed $\mathrm{HiL}_{\text {Old70 }}-\mathrm{HiL}_{\text {Old80 }}$ vs. HiL ${ }_{\text {new90 }}$ contrast categories, the highest yielding late $\mathrm{cv}$. 'Kadett'

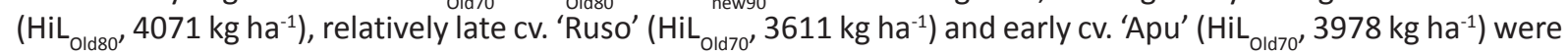
clearly inferior in yielding capacity compared with the most common wheat in cultivation, cv. 'Tjalve' (HiL ${ }_{\text {new90, }}$ $\left.4563 \mathrm{~kg} \mathrm{ha}^{-1}\right)$. Also the 1000 grain weight and protein content were superior with cv. 'Tjalve' (38.7 g, 13.2\%) compared with cv. 'Kadett' (37.7 g, 9.2\%), cv. 'Ruso' (36.8 g, 10.3\%), cv. 'Apu' (30.6 g, 9.8\%).

According to the Path coefficient results, the high yielding genotypes especially in the HiL category expressed the source-sink covariances in a well balanced and optimal combination (Eq. 1). The cv. 'Kadett', with highest sink capacity (grain yield and dry matter accumulation) in the $\mathrm{HiL}_{\text {old80 }}$ category, also had a high source capacity (e.g. flag leaf area and dry weight). With lowest yielding cultivar Tähti $\left(\mathrm{HiL}_{\text {old70 }}\right)$, the source-sink imbalance and inadequate translocation of assimilates were potentially yield limiting factors (Reynolds et al. 2007, Sinclair and Jamieson 2008).

The Cultivation scoring value $\left(\mathrm{C}_{\mathrm{ValTot}}\right)$ results indicated that mid-European genotypes belonging to the Elite and MidE${ }_{\text {New90 }}$ classes obtained the highest total scoring sums. Especially cv. 'Quarna' ( $C_{a} 23, C_{b} 39, C_{c} 22, C_{p} 39$ ) obtained the highest $C_{\text {valTot }}$ value (123) in MidE ${ }_{\text {New90 }}$ and Elite classes. Respectively, cv. 'Marble' $\left(C_{a} 25, C_{b} 31, C_{c} 28, C_{p} 33\right)$ obtained the highest total scoring value (117) in the $\mathrm{HiL}_{\mathrm{New90}}$ and Elite classes. The mid-European genotype 'Trappe' (MidENew90, Other class) with a relatively low Cultivation Value profile $\left(C_{a} 22, C_{b} 34, C_{c} 27, C_{p} 24, C_{\text {ValTot }} 103\right)$, produced the highest grain yield level $\left(6 \mathrm{t} \mathrm{ha}^{-1}\right)$. The Mixed baseline estimate $\left(\mathrm{y}_{\mathrm{b}}\right)$ for $\mathrm{cv}$. 'Trappe' was $6240 \mathrm{~kg} \mathrm{ha-1}$. Cv. 'Quarna' yielded $4730 \mathrm{~kg} \mathrm{ha}^{-1}$. In the ( $\mathrm{HiL}_{\mathrm{New} 90}$, Elite) category, the highest yielding cultivar was cv. 'Marble' $\left(5120 \mathrm{~kg} \mathrm{ha}^{-1}\right)$.

In the $\mathrm{C}_{\mathrm{a}}$ component (adaptation plasticity), $\mathrm{cv}$. 'Wellamo' ( $\mathrm{HiL}_{\mathrm{New90}}$, Elite class) had the highest adaptation plasticity value $\left(C_{a} 27\right)$. The growing period from sowing to full maturity was longer in the $\mathrm{MidE}_{\mathrm{New90}}$ category. $\mathrm{Cv}$. Trappe had the longest growing period from sowing to full maturity $(110 \mathrm{~d})$. The $\mathrm{C}_{\mathrm{a}}$ values and the growing days were for cv. 'Trappe', 'Quarna' and 'Marble' (22/110 d, 23/104 d, 25/107 d).

The Cultivation certainty $\left(C_{c}\right)$ component results indicated that the final grain yield levels with high yielding cultivars were higher in the $\mathrm{MidE}_{\mathrm{New90}}$ category than in the $\mathrm{HiL}_{\mathrm{New90}}$ category. The highest cultivation certainty $\left(\mathrm{C}_{\mathrm{c}} 36\right)$ was with cv. 'Amaretto' (HiL ${ }_{\text {New9o }}$, Elite).

When analyzing the variation between high yielding cultivars in the Cultivation properties component $\left(C_{p}\right)$, the accumulated grain yield/growing day ratio $\left(\mathrm{DM} \mathrm{d}^{-1} \mathrm{ha}^{-1}\right.$ ) and the nitrogen amount in grains ( $\mathrm{N} \mathrm{kg} \mathrm{ha-1)}$ were significant. The $C_{p}$ values, the grain yield accumulation/growing day ratio and the nitrogen amount in grains were for cv. 'Trappe', 'Quarna' and 'Marble' (30/55/104, 39/46/109 and 33/48/101). Cv. 'Quarna' had the highest $C_{p}$ value (39), highest baking quality $\left(C_{q} 39\right)$ and the highest nitrogen amount in grains (109). Cv. 'Trappe' had the highest grain yield accumulation/growing day ratio (55) and the longest growing period enabling an effective translocation system from the source (flag leaf and second highest leaf) to the sink organs (head and grains) during grain filling phase, therefore contributing to the high final grain yield level.

\section{Implications from the ideotype profile analysis for generic HiL and MidE wheat genotypes}

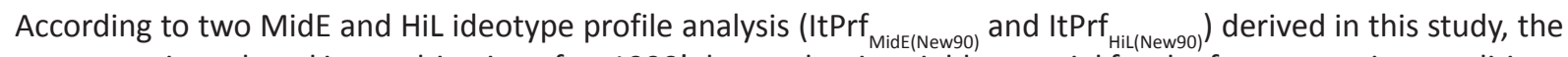
genotypes introduced into cultivation after 1990's have adaptive yield potential for the future growing conditions with elevated temperature and atmospheric $\mathrm{CO}_{2}$ growing conditions. The modeling results for generic ItPrf ${ }_{\text {MidE(New90) }}$ and $\mathrm{ItPrf}_{\mathrm{HiL(New90)}}$ ideotypes indicated that the non-potential baseline yield $\left(\mathrm{V}_{\mathrm{b}}, \mathrm{kg} \mathrm{ha}^{-1}\right)$ comparison without the concurrent $\mathrm{CO}_{2} \times$ temperature covariance effect yielded the baseline yield difference $\left(\Delta \mathrm{y}_{\mathrm{b}}\right) 140 \mathrm{~kg} \mathrm{ha}^{-1}(+102 \%)$ for ItPrfMidE $_{(\text {New9) })}$ vs. ItPrfHiL ${ }_{(\text {New90) }}\left(y_{b} 4620 \mathrm{~kg} \mathrm{ha}^{-1}, 100 \%\right)$. 
When taking into account also the projected concurrent $\mathrm{CO}_{2} \times$ temperature covariance effect $\Delta \mathrm{y}_{\mathrm{b}}\left(\mathrm{CO}_{2^{\prime} 700 \mathrm{ppm}}, \Delta \mathrm{T}_{+33^{\circ} \mathrm{C}}\right)$ projected by the year 2100 climate change scenario for southern Finland (Carter 2004), the non-potential average baseline yield change $\left(\Delta \mathrm{y}_{\mathrm{b}}, \%\right)$ would be $1.035 \%$ (range 1.01-1.06\%) for the generic ItPrf ${ }_{\text {HiL(New90) }}$ ideotype. Correspondingly the average $\Delta \mathrm{y}_{\mathrm{b}}$ change for the generic ItPrf ${ }_{\text {MidE(New90) }}$ ideotype would be $1.085 \%$ (range 1.04$1.13 \%)$. These results indicate that the ItPrf ${ }_{\text {MidE(New90) }}$ non-potential baseline yield $\left(\mathrm{y}_{\mathrm{b}}\right)$ would be on average 5150 $\mathrm{kg} \mathrm{ha}^{-1}$ level $\left(\Delta \mathrm{y}_{\mathrm{b}}+108 \%\right)$ vs. ItPrf ${ }_{\text {HiL(New90) }}$ ideotype $\left(\mathrm{y}_{\mathrm{b}} 4770 \mathrm{~kg} \mathrm{ha}^{-1}, 100 \%\right)$ and assuming the photoperiodical day length remains constant.

\section{Implications for future adaptation strategies using high yielding spring wheat ideotypes}

Previous crop simulation results with the CERES-Wheat crop model (Laurila 2001), Open Top Chamber crop physiological results (Hakala et al. 2005) for cv. 'Polkka' ( $\mathrm{HiL}_{\text {old80 }}$ ) and for cv. 'Nandu' (MidE ${ }_{\text {New9o }}$ ) indicated, that the concurrent elevated atmospheric $\mathrm{CO}_{2}$ concentration and elevated diurnal temperature will increase the yield potential of the HiL wheat genotypes by $1-6 \%$ and by $4-13 \%$ with the MidE wheat genotypes in southern Finland. Badger (1992) stated that wheat ideotypes with optimum yielding capacity and with adaptation for elevated atmospheric $\mathrm{CO}_{2}$ concentration should have a fast canopy closure at tillering stage and a long grain filling period with high temperature sum requirements from anthesis to maturity. According to Slafer \& Savin (1997) the elevated atmospheric $\mathrm{CO}_{2}$ concentration (720 ppm) did not affect significantly the phyllochron leaf appearance rate (PHINT) or the phenological development in vegetative or generative phases with winter and spring wheat genotypes. The CERES-Wheat crop model takes into account the photoperiodism by using the phenological genetic coefficient P1D, which is linked to PHINT coefficient affecting genotype phyllochron interval and leaf appearance rate (Jones et al. 2003). According to Kontturi (1979) and Saarikko (1999) the Effective Temperature Sum (ETS) requirement of $1050 \pm 30^{\circ}$ degree-days ( $\mathrm{dd}, \mathrm{Tb}+5^{\circ} \mathrm{C}$ ) from sowing to yellow ripening stage is considered adequate for HiL spring wheat genotypes grown in zones I-IV in Finland. According to Peltonen (2010) new MidE $_{\text {New9o }}$ genotypes require higher ETS values, exceeding the 1000 dd for full maturity in cultivation zones I-II, e.g. cv. 'Trappe' (1052 dd) and cv. 'Picolo' (1092 dd). The average ETS requirements with new HiL ${ }_{\text {New9o }}$ genotypes are for cv. 'Mahti' (985 dd), cv. 'Tjalve' (996 dd), cv. 'Anniina' (962 dd), cv. 'Aino' (968 dd).

In this study, the Mixed structural covariance and Cultivation value results indicated a significant increase in baseline yield $\left(\mathrm{y}_{\mathrm{b}}, \mathrm{kg} \mathrm{ha}^{-1}\right)$ trends between new and old genotypes (HiL/MidE ${ }_{\text {old70, old80 }} \mathrm{vs.} \mathrm{HiL/MidE}{ }_{\text {New9o }}$ ). Results indicated that new HiL and MidE genotypes introduced into cultivation after $1990 \mathrm{~s}\left(\mathrm{HiL} / \mathrm{MidE}_{\mathrm{New9}}\right)$ have a significantly higher yielding capacity between $9 \%$ and $13 \%$ vs. HiL/MidE ${ }_{\text {old70, old80 }}$ genotypes. In addition, results indicated a consistently higher yielding capacity (108\%) for MidE ${ }_{\text {New9o }}$ genotypes compared with $\mathrm{HiL}_{\text {New90 }}$ genotypes (100\%). Results from the Cultivation value analysis indicated, that especially MidE cultivars belonging to the MidE ${ }_{\text {New9o }}$ and Elite classes obtained the highest Cultivation value ratings and produced the highest final grain yield levels.

If the concurrent elevated atmospheric $\mathrm{CO}_{2}$ concentration (700 ppm) and elevated diurnal temperature $(+3 \stackrel{\circ}{\circ})$ increase is also taken into account in the adaptation strategies, the MidE $_{\text {New9o }}$ non-potential baseline yield levels $\left(y_{b}\right)$ will be permanently surpassing the $5 \mathrm{t} \mathrm{ha}^{-1}$ barrier by 2100 in southern Finland. The ideotype profile results obtained in this study also support this increasing yield trend for new HiL and MidE ideotypes. However, these modeled yield levels for generic MidE and Nordic HiL wheat ideotypes comprise only $50 \%$ of the theoretical maximum yielding capacity level of $10 \mathrm{t} \mathrm{ha}^{-1}$ reported by Austin et al. (1980).

\section{Conclusions}

Modeling results obtained in this study with Mixed structural covariance analysis indicated that new high-latitude and mid-European ideotypes, introduced into cultivation after 1990s, have a significantly higher yield capacity compared with genotypes introduced for cultivation earlier. New mid-European genotypes produced a consistently higher yielding capacity (108\%) than high-latitude genotypes (100\%). These modeling results are supported by both practical field results on farm level in southern Finland (2009-2010) and also by MTT Agrifood Research Finland 1978-2007 official wheat variety trial results indicating a general trend of breaking the $5 \mathrm{t}^{-1}$ baseline yield barrier with new high yielding mid-European and high-latitude genotypes.

Path coefficient modeling results for high-latitude genotypes suggested, that especially grains/ear, harvest index (HI) and maximum 1000 kernel weight were significant factors defining the highest yield potential. Cultivation 
Value modeling results indicated, that especially genotypes belonging to Elite class inside $\mathrm{MidE}_{\mathrm{New} 90}$ and $\mathrm{HiL}_{\mathrm{New90}}$ Mixed contrast categories, obtained the highest Cultivation scoring values.

Spring wheat modeling results obtained in this study can be utilized when designing new wheat genotypes with optimal ideotype profiles for agricultural adaptation strategies. Especially the wheat adaptation plasticity $\left(\mathrm{C}_{\mathrm{a}}\right)$, cultivation certainty $\left(C_{c}\right)$ and cultivation property $\left(C_{p}\right)$ components are important selection factors when breeding the future wheat ideotypes adapted for elevated temperatures and $\mathrm{CO}_{2}$ growing conditions in northern latitudes. The modeling results obtained in this study with new high yielding MidE and HiL ideotypes (MidE ${ }_{\text {New90, }} \mathrm{HiL}_{\text {New90 }}$ ) imply that the mid-European non-potential baseline yield $\left(\mathrm{y}_{\mathrm{b}}\right)$ would be on average $5150 \mathrm{~kg} \mathrm{ha}^{-1}(+108 \%)$ vs. high-latitude ideotypes $\left(\mathrm{y}_{\mathrm{b}} 4770 \mathrm{~kg} \mathrm{ha}^{-1}, 100 \%\right)$ grown under the elevated $\mathrm{CO}_{2(700 \mathrm{ppm})} \times$ temperature ${ }_{\left(+3^{\circ} \mathrm{C}\right)}$ growing conditions projected by the year 2100 climate change scenario in southern Finland.

\section{Acknowledgments}

We wish to express our sincere gratitude to Dr. Ari Rajala, Dr. Reijo Karjalainen, Dr. Kaija Hakala, MSci. Tapani Kangasmäki and Dr. Riitta Saarikko (MTT Agrifood Research of Finland) for providing the wheat genotype field data, support for statistical analysis and reviewing the manuscript versions. Appreciation is also acknowledged for Professor Pirjo Peltonen-Sainio (MTT Agrifood Research of Finland), Dr. Mervi Seppänen (Helsinki University, Department of Agricultural Sciences) and Professor Timothy Carter (The Finnish Environment Institute) for their support.

†This publication is dedicated to the memory of late Dr. Jari Peltonen.

\section{References}

Aula, S. \& Talvitie, H. 1995. The suitability of rye and spring wheat varieties for ecological Cultivation. Research Note 3. Jokioinen: MTT Agrifood Research Finland. 42 p.

Austin, R., J. Bingham J. \& Evans, L. 1980. Genetic improvement in winter wheat yields since 1900 and associated physiological changes. Journal of Agricultural Science 40: 675-689.

Badger, M. 1992. Manipulating agricultural plants for a future high $\mathrm{CO}_{2}$ environment. Australian Journal of Botany 40: 421-429.

Boote, K., M. J. Kropff, K. \& Bindraban, P. 2001. Physiology and modeling of traits in crop plants:Implications for genetic improvement. Agricultural Systems 70: 395-420.

Carter, T. R. 2004. FINSKEN: Global change scenarios for Finland in the 21st century. Boreal Environmental Research 9: 89. Available on the Internet: www.borenv.net/BER/pdfs/ber9/ber9-089.pdf, http://www.finessi.info/finsken

Carvalho, F. I. F. \& de Qualset, C. O. 1978. Genetic variation for canopy architecture and its use in wheat breeding. Science 18: 561-567.

Dewey, D. R. \& Lu, K. H. 1959. A Correlation and Path- coefficient analysis of components of crested wheat grass seed production. Agrononomy Journal 23: 106-117.

Donald, C.M., 1968. The breeding of crop ideotype. Euphytica 17: 385-403.

Donald, C.M. \& Hamblin, J. 1983. The convergent evolution of annual seed crops in agriculture. Advances in Agrononomy 36: 97-143. Falconer, D.S. \& Mackay. T.F. 1996. Introduction to Quantitative Genetics. $4^{\text {th }}$ Edition. Essex, England: Pearson Education Ltd. 464 p. Gent, M.P.N. \& Kiyomoto.R.K. 1985. Comparison of canopy and flag leaf net carbon dioxide exchange in 1920 and 1977 New York winter wheats. Crop Science 25: 81-86.

Hakala, K. 1998. Growth and yield potential of spring wheat in a simulated changed climate with increased $\mathrm{CO}_{2}$ and higher temperature. European Journal of Agronomy 9: 41-52.

Hakala, K., Heliö R., Tuhkanen E. \& Kaukoranta T. 1999. Photosynthesis and Rubisco kinetics in spring wheat and meadow fescue under conditions of simulated climate change with elevated $\mathrm{CO}_{2}$ and increased temperatures. Agricultural and Food Science in Finland 8: 441-457.

Hakala, K., Laurila, H. \& Mela, T. 2005. Increase in atmospheric $\mathrm{CO}_{2}$ and ambient temperatures in the North: promises and drawbacks for crop production. In: Tuba Z. (ed.). Journal of Crop Production, Special volume Production Ecological Responses and Adaptations of Crops to Rising Atmospheric Carbon Dioxide. Oxford: Haworth Press. 13: 239-255.

IIASA. 2010. The International Institute for Applied Systems Analysis (IIASA). Homepage.Cited 9 September 2010. Available on the Internet: www.iiasa.ac.at.

IPCC. 2007. Intergovernmental Panel on Climate Change. Climate Change 2007, the Fourth IPCC Assessment Report. Cited 9 September 2010. Available on the Internet: www.ipcc.ch/ipccreports/index.htm, www.ipcc.ch/ipccreports/assessments-reports.htm.

Jones,J.W., Hoogen, G.,Porter,C.H, Boote,K.J.,Batchel, W.D., Hunt,L.A., Wilkens, P.W., Singh, U., Gijsman A.J.,Ritchie J.T. 2003. The DSSAT cropping system model. European Journal of Agronomy 18: 235-265.

Järvi, A., Kangas, A. \& Rahkonen, H. 1997. Results of Official Variety Trials 1989-1996. Report 19. Jokioinen: MTT Agrifood Research Finland. 205 p. 
Kangas, A., Laine, A., Niskanen, M., Salo, Y., Vuorinen, M., Jauhiainen, L. \& Nikander, H. 2006. Results of Official Variety Trials 2000-2007. Report 105. Jokioinen: MTT Agrifood Research Finland. Cited 11 November 2009. Available on the Internet: http:// www.mtt.fi/mtts/pdf/mtts105.pdf.

Kangas, A., Laine, A., Niskanen, M., Salo, Y., Vuorinen, M., Jauhiainen, L. \& Nikander, H. 2008. Results of Official Variety Trials 2000-2007. Report 150. Jokioinen: MTT Agrifood Research Finland. Cited 11 November 11 2009. Available on the Internet: http:// www.mtt.fi/mtts/pdf/mtts150.pdf.

Kuusisto, E., Kauppi L. \& Heikinheimo, P. 1996. Ilmastonmuutos ja Suomi. (Climate change and Finland). Helsinki: Yliopistopaino, Helsinki University Press (in Finnish).

Kontturi, M. 1979. The Effects of Weather on Yield and Development of Spring Wheat in Finland.Annales Agriculturae Fenniae 18: $263-274$.

Laurila, H. 1995. Modeling the effects of elevated $\mathrm{CO}_{2}$ and temperature on Swedish (cv. Polkka) and German (cv. Nandu) spring wheat (Triticum aestivum L.) varieties with CERES-Wheat and AFRC-wheat crop models. Journal of Geobiography 22: 591-595.

Laurila, H. 2001. Simulation of spring wheat (cv. Polkka) responses to elevated $\mathrm{CO}_{2}$ and temperature by using CERES-wheat crop model. Agricultural and Food Science in Finland 10: 175-196.

Laurila, H., Karjalainen, M., Hyyppä, J. \& Kleemola, J. 2010a. Integrating Vegetation Indices Models and Phenological Classification with Composite SAR and Optical Data for Cereal Yield Estimation in Finland. Special Issue Microwave Remote Sensing. Remote Sensing 2: 76-114.

Laurila, H., Karjalainen, M., Kleemola, J. \& Hyyppä, J. 2010b. Cereal Yield Modeling in Finland Using Optical and Radar Remote Sensing. Special Issue Global Croplands. Remote Sensing 2: 2185-2239. Available on the Internet: http://www.mdpi.com/20724292/2/9/2185/

Ledent, J.F. 1979. Relationships between grain yield and morphological characters in the winter wheat genotypes of the Belgian national list. Biologium Plantarum 21: 161-169.

Li, C. 1974. Path-analysis- a primer. The Boxwood Press California. 346 p.

Littel, R., Milliken, G., Stroup, W. \& Wolfinger R. 1996. SAS System for Mixed models. SAS Institute. 615 p.

Mela, T. \& Suvanto, T. 1987. Peltokasvien satoennuste vuoteen 2000 mennessä. Peltokasvien satojen ja niihin vaikuttavien tekijöiden kehitys vuoteen 2000 mennessä. (The estimation of field crop yield levels by the year 2000). Helsinki Helsinki University, Department Of Crop Production Publication no: 14. 45 p. (in Finnish).

Mäkelä, P., Väärälä \& L. Peltonen-Sainio, P. 1996. Agronomic comparison of Minnesota-adapted dwarf oat with semi-dwarf, intermediate, and tall oat lines adapted to northern growing conditions. Canadian Journal of Plant Science 76:727-734.

Passioura, P. 2006. Increasing crop productivity when water is scarce-from breeding to field management. Agricultural Water Management 80: 176-196.

Peltonen, J., Juuti T. \& Salopelto J. 1993. The bread making quality of Finnish spring wheats - a proposal for classification. Agricultural Science in Finland 2:507-51.

Peltonen, J. 2010. Viljelyarvot vertailussa (Comparison of spring wheat cultivation values in Finland).Pellervo 2:35-42 (in Finnish).

Peltonen-Sainio, P. 1992. Description of a productive oat ideotype characterized by morpho-physiological traits associated with high grain yield. Thesis. Univ. of Helsinki, Dept. of Plant Production, Crop Husbandry Section. Publication no. 34.52 p.

Peltonen-Sainio P., Rajala A. \& Seppälä T. 2005. ABC of cereal development and growth.(In Finnnish). Cited 19 August 2008. Available on the Internet: www.mtt.fi/met/pdf/met67.pdf.

Peltonen-Sainio, P. \& Rajala, A. 2007. Duration of vegetative and generative development phases in oat cultivars released since 1921. Field Crops Research 101: 72-79.

Peltonen-Sainio, P., Lauri Jauhiainen, L \& Laurila, I.P. 2009. Cereal yield trends in northern European conditions: Changes in yield potential and its realization. Field Crops Research 110: 85-90.

Rajala, A., Hakala, K., Mäkelä, P., Muurinen \& S. Peltonen-Sainio, P. 2009. Spring wheat response to timing of water deficit through sink and grain filling capacity, Field Crops Research: 114: 263-271.

Reynolds, M.P., Acevedo,E., Sayre, K.D. \& Fisch, R.A. 1994. Yield potential in modern wheat varieties: its association with a less competitive ideotype. Field Crops Research: 37: 149-160.

Reynolds, M., Calderini, D., Condon, A. \& Vargas, M. 2007. Association of source/sink traits with yield, biomass and radiation use efficiency among random sister lines from three wheat crosses in a high-yield environment. Journal of Agricultural Science: 145: 3-16.

Ritchie, J.T. \& Otter, S. 1985. Description and Performances of CERES-Wheat: A User oriented Wheat Yield Model. USDA, Agricultural Research Service ARS 38: 159-175.

Ritchey, R. 1996. Analysis and synthesis - On Scientific Method. Systems Research 4: 21-41.

Saarikko R. A., Pihala, M.T., Hannukkala A. \& Carter T.A. 1996. Greenhouse and field experiments on the effects of increased temperature on wheat, maize and potato. In: Harrison P. A., Butterfield R.E., Downing T.E. (eds.). Climate change, Climatic Variability and Agriculture in Europe, An Integrated Assessment, Annual Report. Environmental Change Unit, Univ. of Oxford. p. 34-39.

Saarikko R. A. 1999. Climate Change and Crop Potential in Finland: Regional Assessment of Spring Wheat. Thesis. University Of Helsinki.Department of Plant Production. Publication no. 55. 125 p.

Sadras, V.O.,Reynolds,M.P., de la Vega,A.J., Petrie, P.R., Robinson, R.2009. Phenotypic plasticity of yield and phenology in wheat, sunflower and grapevine. Field Crops Research 110: 242-250.

SAS. 1990. SAS/Stat User's Guide I-II. Version 6. SAS Inst. Inc. Cary NC. USA. 1686 p. 
Sedgley, R.H. 1991. An appraisal of the Donald ideotype after 21 years. Field Crops Research 26: 93-112.

Siddiqui, K.A., Rajput, M.A. \& Tahir, K.H. 1980. Path- coefficient analysis of yield components in mutants of Triticum aestivum. Genetic Agriculture 34: 89-100.

Sinclair, T.R. \& Jamieson, P.D. 2008. Yield and grain number of wheat: A correlation or causal relationship. Field Crops Research105: 22-26.

Slafer, G.A \& Savin., R. 1994. Source-sink relationships and grain mass at different positions within the spike in wheat. Field Crops Research 37: 39-49.

de la Vega, A., J. Hall, J. \& Kroonenberg P. 2002. Investigating the physiological bases of predictable and unpredictable genotype by environment interactions using three-mode pattern analysis. Field Crops Research 78: 165-183.

Weizensorten und Backqualität 1990. Beschreibe Sorteliste fur Getreide, Mais, Ölfructhe, Leguminosen (Grosskörnig), Hackfruchte (ausser Kartoffeln). Herausgegeben vom Bundessortenamt, Hannonver, Germany, p. 80-93.

Wright S. 1923. The theory of path coefficients. Genetics 8: 239-255.

Zadoks, J.C, Chang, T.T. \& Konzak, C.F. 1984. A decimal code for the growth stages of cereals. Weed Research 14: 415-421.

Öfversten, J. \& Nikander, H. 1996. Lajikekoesarjojen analysointi (Analysis of series of crop variety trials). Maatalouden tutkimuskeskuksen julkaisuja. Serie B. (in Finnish). Jokioinen: Agricultural Research Centre of Finland. 39 p. 


\section{Appendix 1}

Table 10. Definitions and abbreviations.

\begin{tabular}{|c|c|c|}
\hline $\begin{array}{l}\text { Definition, } \\
\text { abbreviation }\end{array}$ & Unit, [range] & Explanation \\
\hline $\mathrm{X}$ & & Mean of sample \\
\hline SD & & Standard deviation of sample (n) \\
\hline SEM & $\begin{array}{l}\text { Standard error } \\
\text { of mean }\end{array}$ & Standard error of mean $=\underline{\mathrm{SD}}$ \\
\hline RMSD & $\mathrm{d}, \mathrm{t} \mathrm{ha} \mathrm{-}^{-1}$ & Root Mean Square Difference algorithm (Laurila, 2001) \\
\hline$C_{v}$ & $\%$ & Coefficient of variation $(\%)=S D / X$ \\
\hline Ref. & & Reference genotype/cultivar/variety in field trials (Table 1) \\
\hline$V_{p}$ & & Phenotype variation (Eq. 1, Falconer \& Mackay, 1996) \\
\hline $\mathrm{V}_{\mathrm{g}}$ & & Genotype variation (Eq. 1) \\
\hline $\mathrm{V}_{\mathrm{e}}$ & & Environmental variation (Eq. 1) \\
\hline $\mathrm{COV}_{\mathrm{ge}}$ & & Genotype x environmental covariance variation in broad sense (Eq. 1) \\
\hline $\begin{array}{l}\text { Potential } \\
\text { non-limited } \\
\text { yield, } \\
\text { yield } \\
\text { potential }\end{array}$ & $\begin{array}{l}\mathrm{kg} \mathrm{ha}^{-1}, 15 \% \\
\text { moisture } \\
\text { content }\end{array}$ & $\begin{array}{l}\text { Modeled maximum yield capacity and yield potential }\left(\mathrm{kg} \mathrm{ha}^{-1}\right) \text { for a specific genotype without limiting } \\
\text { environmental stress factors during growing season (vegetation water stress, nutrient deficiencies, pathogen } \\
\text { epidemics etc.) }\end{array}$ \\
\hline $\begin{array}{l}\text { Non- } \\
\text { potential, } \\
\text { limited yield }\end{array}$ & $\begin{array}{l}\mathrm{kg} \mathrm{ha}^{-1}, 15 \% \\
\text { moisture }\end{array}$ & $\begin{array}{l}\text { Modeled yield level (kg ha-1) for a specific genotype with limiting environmental stress factors during growing } \\
\text { season reducing maximum yield capacity, see potential yield. }\end{array}$ \\
\hline$y_{b}$ & $\begin{array}{l}\mathrm{kg} \mathrm{ha}^{-1}, 15 \% \\
\text { moisture } \\
\text { content }\end{array}$ & $\begin{array}{l}\text { Modeled baseline yield estimate for a cereal genotype growing under non-optimal field growing conditions. } \\
\text { See potential and non-potential yield. } \\
\Delta y b-\text { Modeled baseline yield difference }(\%) \text { between genotypes }\end{array}$ \\
\hline$\Delta \mathrm{y}_{\mathrm{b}(\mathrm{CO} 2,700 \mathrm{ppm})}$ & $\begin{array}{l}\text { \%, change range } \\
\text { (min. - max.) }\end{array}$ & Change (\%) on $\mathrm{y}_{\mathrm{b}}$ (baseline yield, $\mathrm{kg} \mathrm{ha}^{-1}$ ) with doubled atmospheric $\mathrm{CO}_{2}$ concentration (700 ppm, Carter 2004) \\
\hline$\Delta \mathrm{y}_{\mathrm{b}\left(\Delta \mathrm{T},+3^{\circ} \mathrm{C}\right)}$ & $\begin{array}{l}\text { \%, change range } \\
\text { (min. - max.) }\end{array}$ & $\begin{array}{l}\text { Change }(\%) \text { on } \mathrm{y}_{\mathrm{b}} \text { (baseline yield, } \mathrm{kg} \mathrm{ha}^{-1} \text { ) with }+3^{\circ} \mathrm{C} \\
\text { mean diurnal temperature change }(\text { Carter 2004) }\end{array}$ \\
\hline$\Delta \mathrm{y}_{\mathrm{b}(\mathrm{CO} 2 \text {, TempCov })}$ & $\begin{array}{l}\%, \text { change range } \\
\text { (min. - max.) }\end{array}$ & $\begin{array}{l}\text { Covariance mean change }(\%) \text { on } \mathrm{y}_{\mathrm{b}}\left(\text { baseline yield, } \mathrm{kg} \mathrm{ha}^{-1}\right) \\
\text { with concurrent doubled atmospheric } \mathrm{CO}_{2} \text { concentration }(700 \mathrm{ppm}) \text { and with }{ }_{+3^{\circ} \mathrm{C}} \text { mean diurnal temperature } \\
\text { change (Carter 2004) }\end{array}$ \\
\hline $\mathrm{C}_{\text {ValTot }}$ & & Cultivation total scoring value of a genotype in growing zones I-III \\
\hline $\mathrm{C}_{\mathrm{a}}$ & & Adaptation Value in Cultivation Value model \\
\hline $\mathrm{C}_{\mathrm{q}}$ & & Cultivation Quality in Cultivation Value model \\
\hline $\mathrm{C}_{\mathrm{c}}$ & & Cultivation Certainty in Cultivation Value model \\
\hline $\mathrm{C}_{\mathrm{b}}$ & & Baking Quality in Cultivation Value model \\
\hline $\mathrm{HiL}$ & & high-latitude genotype/ideotype (growing latitude $>60^{\circ} \mathrm{N}$ ) \\
\hline MidE & & mid-European genotype/ideotype (growing latitude $<60^{\circ} \mathrm{N}$ ) \\
\hline ItPrf $_{\text {(HiL,Mide) }}$ & & Donald's ideotype profiles for generic HiL and MidE genotypes (Donald, 1968) \\
\hline Ref. & & $\begin{array}{l}\text { Reference genotype/cultivar in the corresponding category in the statistical analysis or in the dynamic model. } \\
\text { Dependent or response variable is scaled to relative base value in the category ( } 1 \text { or 100). }\end{array}$ \\
\hline$r_{a}, r_{b}, . r_{x}$ & {$[0 . .1 .0]$} & Correlation coefficients for independent variables, indirect effects in Path-model (Eq. 5, Table 6) \\
\hline$p_{a}, p_{b, . .} p_{x}$ & {$[0 . .1 .0]$} & Path-coefficients for independent variables, direct effects in Path-model (Eq. 4) \\
\hline$p_{v}$ & {$[0 . .1 .0]$} & Vegetation Path-coefficient (Table 7) \\
\hline $\mathrm{p}_{\mathrm{y}}$ & {$[0 . .1 .0]$} & Yield Component Path-coefficient (Table 8) \\
\hline $\mathrm{U}$ & & Residual factor, the variance not explained by the Path coefficient model (Eq. 6). \\
\hline $\mathrm{R}^{2}$ & {$[0 . .1 .0]$} & Coefficient of determination, R-square, total variance, explained by the Path-model (Eq. 7) \\
\hline Temperature & degree $\left[\mathrm{C}^{\circ}\right]$ & Mean diurnal temperature as calculated from minimum and maximum values \\
\hline$\Delta \mathrm{T}$ & degree $\left[\mathrm{C}^{\circ}\right]$ & Mean diurnal temperature change \\
\hline $\mathrm{T}_{\mathrm{b}}$ & degree $\left[{ }^{\circ}\right]$ & Threshold temperature \\
\hline dd & degree days $\left[{ }^{\circ}\right]$ & {$\left[{ }^{\circ}\right]$} \\
\hline $\operatorname{ETS}\left(T_{b}\right)$ & dd - degree days & $\begin{array}{l}\text { Cumulative temperature sum over threshold temperature } \\
\left(T_{b}=5^{\circ}\right)\end{array}$ \\
\hline ppm & & Parts per million ( $\mathrm{CO}_{2}$ concentration) \\
\hline $\mathrm{CO}_{2}$ & ppm & Atmospheric $\mathrm{CO}_{2}$ concentration $[\mathrm{ppm}]$ \\
\hline PAR & $\mathrm{MJ} / \mathrm{D} \mathrm{m}^{-2}[10-20]$ & Photosynthetically Active Radiation ( $=400-700 \mathrm{~nm})$ \\
\hline RUE & $\begin{array}{l}\text { DW g * }{ }^{*} J^{-1} \mathrm{~d}^{-1} \\
\text { [PAR: } 1.0-5.0, \\
\text { Glob. Rad. 0.5- } \\
\text { 2.5] }\end{array}$ & Radiation Use Efficiency: Dry matter (DM) increase/ absorbed PAR or global radiation \\
\hline
\end{tabular}


Table 10. Cont.

\begin{tabular}{|c|c|c|c|c|}
\hline $\begin{array}{l}\text { CERES-Wheat } \\
\text { Submodel } \\
\text { Jones et al. } \\
\text { (2003) }\end{array}$ & $\begin{array}{l}\text { Genetic } \\
\text { coefficients }\end{array}$ & $\begin{array}{l}\text { Description, process } \\
\text { or yield component } \\
\text { affected }\end{array}$ & Range & Unit \\
\hline \multirow[t]{4}{*}{$\begin{array}{l}\text { I Phenological } \\
\text { development }\end{array}$} & PHINT & $\begin{array}{l}\text { Phyllochron } \\
\text { (plastochron) interval } \\
\text { as leaf appearance } \\
\text { rate. Measures the age } \\
\text { of a plant dependent } \\
\text { on morphological } \\
\text { traits rather than on } \\
\text { chronological age. }\end{array}$ & $<100$ & $\begin{array}{l}\text { dd } \\
{ }^{\circ} \mathrm{Cd} \\
\text { leaf }^{-1}\end{array}$ \\
\hline & P1V & Vernalization & $0-9$ & - \\
\hline & P1D & Photoperiodism & $1-5$ & - \\
\hline & P5 & Grain filling duration & $1-5$ & - \\
\hline \multirow[t]{3}{*}{$\begin{array}{l}\text { II Yield } \\
\text { component }\end{array}$} & G1 & $\begin{array}{l}\text { Grains/ear (GPP), } \\
\text { Grains/m² (GPSM) }\end{array}$ & $1-5$ & - \\
\hline & G2 & 1000-seed weight & $1-5$ & - \\
\hline & G3 & $\begin{array}{l}\text { Spike number, affects } \\
\text { lateral tiller production } \\
\text { (TPSM) }\end{array}$ & $1-5$ & - \\
\hline
\end{tabular}

